\title{
EFFICACY OF VARIOUS FIVE-DAY ESTROUS SYNCHRONIZATION PROTOCOLS
}

\section{IN SHEEP}

\author{
A Thesis \\ Submitted to the Graduate Faculty \\ of the \\ North Dakota State University \\ of Agriculture and Applied Science
}

By

Christen Georgia Jackson

In Partial Fulfillment of the Requirements

for the Degree of

MASTER OF SCIENCE

Major Department:

Animal Sciences

July 2012

Fargo, North Dakota 
Title

EFFICACY OF VARIOUS FIVE-DAY ESTROUS SYNCHRONIZATION

PROTOCOLS IN SHEEP

\section{By}

\section{CHRISTEN GEORIGA JACKSON}

The Supervisory Committee certifies that this disquisition complies with North Dakota State University's regulations and meets the accepted standards for the degree of

\section{MASTER OF SCIENCE}

\section{SUPERVISORY COMMITTEE:}

Dr. Reid Redden

$$
\text { Chair }
$$

Dr. Carl Dahlen

Dr. Kimberly Vonnahme

Dr. Wendy Reed

Approved:

$\frac{\text { July } 5^{\text {th }}, 2012}{\text { Date }}$

$\frac{\text { Dr. Eric Berg }}{\text { Department Chair }}$




\begin{abstract}
The objective of this study was to determine the effects of various estrous synchronization protocols utilizing the five-day controlled internal drug releasing (CIDR) inserts that are infused with progesterone (P4) alone and when coupled with gonadotropin-releasing hormone (GnRH) and prostaglandin (PG) during different breeding seasons. Ewes received either 1 of 4 treatments: 1) Untreated (U); 2) 5 d CIDR (0.3 g P4) insert (C); 3 ) 5 d CIDR and PG at CIDR removal (d 0, P); or 4) GnRH at $5 \mathrm{~d}$ CIDR insertion and PG at CIDR removal (G). In Experiment 1 , overall days to estrus were greater $(P \leq 0.01)$ in $\mathrm{U}$ and $\mathrm{P}$ compared with $\mathrm{C}$. In Experiment 2, overall days to estrus were greater $(P \leq 0.02)$ in $\mathrm{U}$ and $\mathrm{P}$ compared with $\mathrm{G}$. In summary, the $5 \mathrm{~d}$ CIDR reduces the number of days required to bring ewes into estrus when compared to untreated ewes.
\end{abstract}




\section{ACKNOWLEDGEMENTS}

Reflecting on the past couple of years that have led me to the closing of my Masters program I have met some exceptional mentors and people I am proud to call my friends and I have gained valuable knowledge and experience I will take with me and cherish forever. First and foremost, I would like to thank my family for all of their love, support, and guidance. Mom and dad, thanks for always being there for me, showing me the importance of hard work and perseverance, and most of all, your love. Tom, Crystal, and Charlie, thanks for always allowing me to have a place to go to if I ever needed to relax, to visit, and yes to do laundry from time to time. I appreciate all that you have done for me while I have been in Fargo. Your support and assistance throughout my studies has been immeasurable. I love you all very much.

I must also give my sincerest gratitude and thanks to the individuals who planted the seed of passion for agriculture in me, for they showed me first hand agriculture in action, the care and desire one must have for their livestock and the great memories that can be made doing something you love. Thank you Hogerville Dairy and the Ledger family for I truly appreciate all that you have done for me from showing at the fairs to allowing me to be a part of your family. All of you will always hold a special place in my heart.

I would like to extend a very special thank you to my advisor, Dr. Reid Redden for taking me on as a masters student even when he was aware of my limited sheep knowledge and experience. The past two years have gone exceedingly fast and I have gained much knowledge and appreciation for the American sheep industry. Thanks for making learning fun through the variety of events I got to help you with from the Shepherds Clinics to the Starter Flock Program and my favorite, the Wool Classing School in Hettinger, N.D. Thanks for always listening to 
me, offering your advice, helping with my research projects, and most of all your patience with me.

A very special thank you to my three co-advisors, Drs. Kimberly Vonnahme, Carl Dahlen, and Wendy Reed. Dr. Vonnahme, thank you for providing me with my first opportunity and exposure to research as undergraduate. It was under your guidance and enthusiasm that I gained gratefulness for research and realized I wanted to further my educational studies. Thanks for all your support, advice, and encouragement along the way. Dr. Dahlen, thanks for supporting me over the past couple years by attending my presentations and seminars and for always offering your advice and knowledge.

I would like to extend a huge thank you to Tammi Neville, Skip Anderson, and the NDSU Sheep Research Unit employees and student workers for all of their help and assistance during my research trials; I couldn't have done it without you.

Lastly, I would like to thank those people who made graduate school more fun and exciting and who lent their advice on how to survive these past couple years! Sharnae, thank you for encouraging me to take GEP with you those many years ago! Had it not been for your encouragement, I may not be where I am today! Thanks for being an awesome roommate the last three years, helping me with my research when it was needed, the late nights up studying and writing, and for being an exceptional friend. I want to thank Erin Harris for being an awesome graduate student mentor. I admire your dedication to research and the swine industry, your skills in SAS, and for being there for me to answer all of my questions I had about my project and graduate school!! Thank you Ely for setting a wonderful example for others and myself to follow. I admire your hard work and dedication, appreciate you offering advice and assistance when needed, and for your friendship over the past several years. To my officemates from the 
old office, Leslie Lekatz and Steve Eckerman, (oh how I miss our old office when it was part of the cleaning closet!) thanks for offering lots of advice my first year as a graduate student and for the fun times. Steve thanks for helping me collect blood samples on my sheep and Leslie thanks for being my workout buddy and encouraging me to start participating in races! It has been fun having a friend to run those with! Thanks to my new officemates, Arshi Reyaz and Megan VanEmon. Its been fun being in your company the past year.

Thank you to those of you watching from above, especially Granny. I know you are with me every day guiding me along my journey. Miss and love you very much. 


\section{TABLE OF CONTENTS}

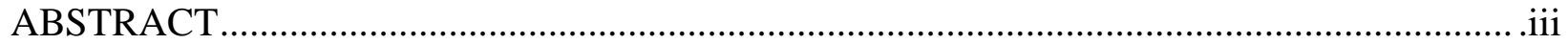

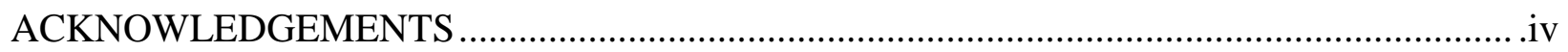

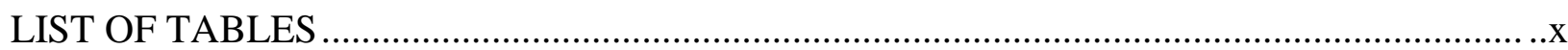

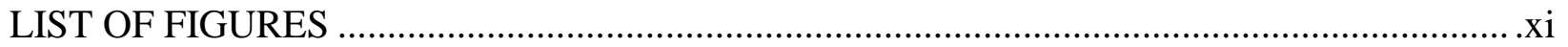

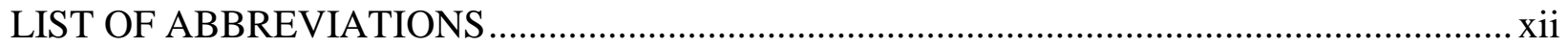

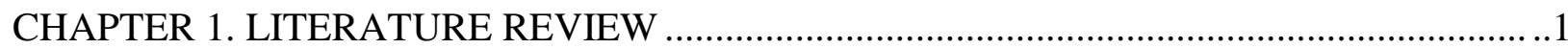

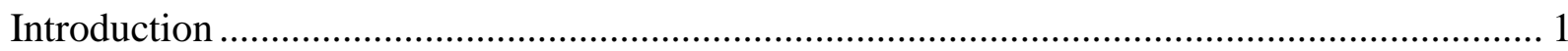

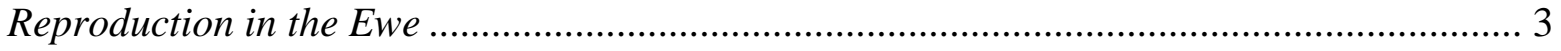

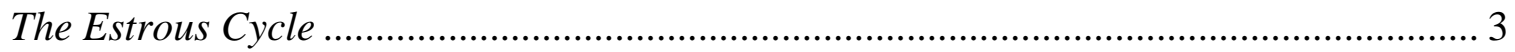

Hormonal Control of the Estrous Cycle .................................................................... 5

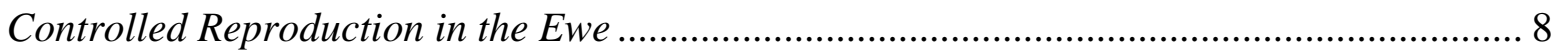

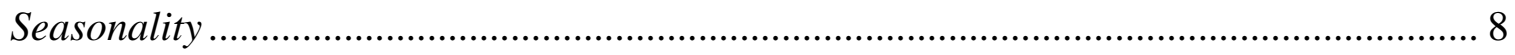

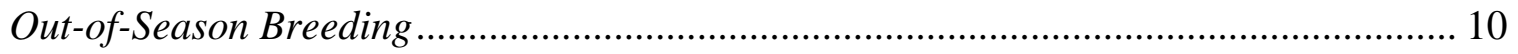

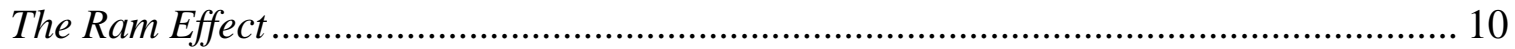

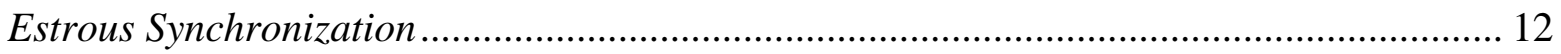

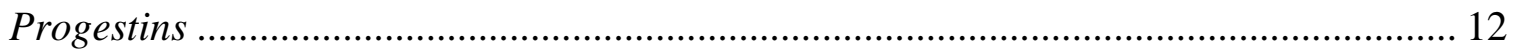

Flurogestone Acetate and Medroxyprogesterone Acetate ............................................ 13

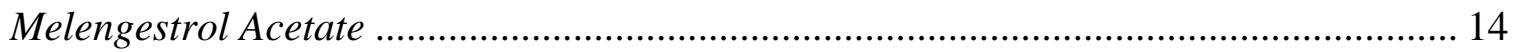

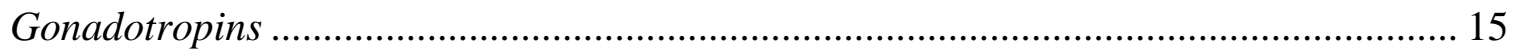


CHAPTER 2. ESTROUS SYNCHRONIZATION IN SHEEP USING GONADOTROPINRELEASING HORMONE, PROSTAGLANDIN, AND CONTROLLED INTERNAL

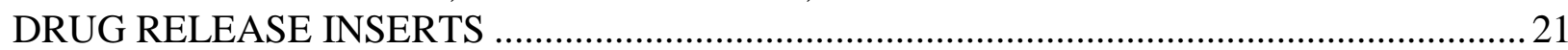

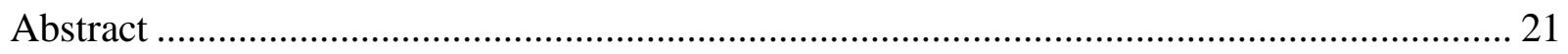

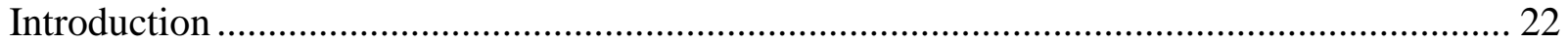

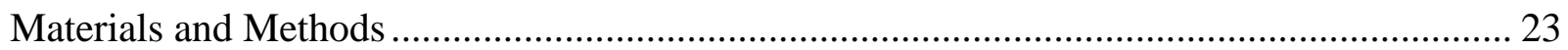

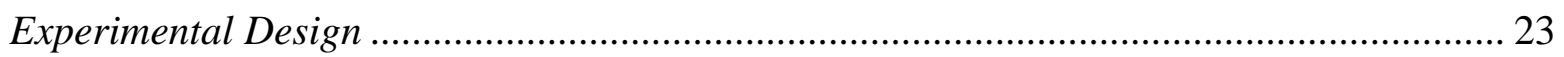

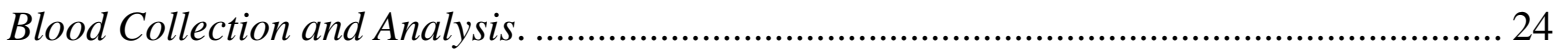

Reproductive Performance …………………………......................................................... 25

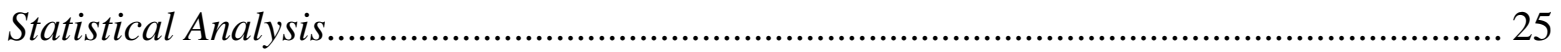

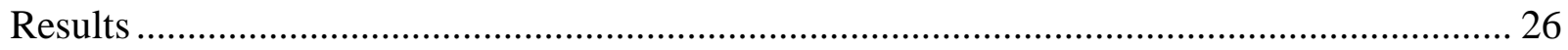

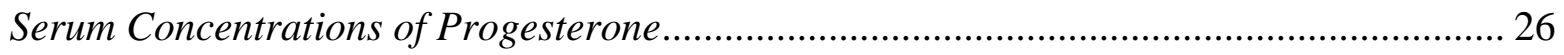

Reproductive Performance Data .................................................................................... 26

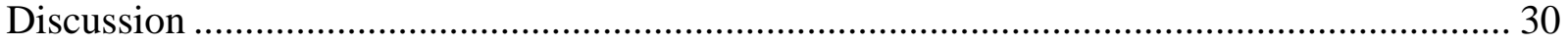

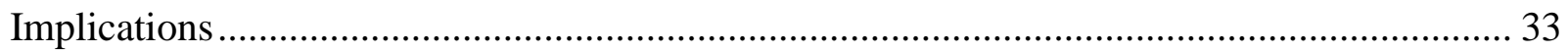

CHAPTER 3. OUT-OF-SEASON REPRODUCTIVE PERFORMANCE OF EWES SYNCHRONIZED TO ESTRUS WITH VARIOUS FIVE-DAY CIDR PROTOCOLS ............. 34

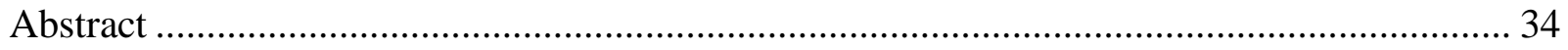

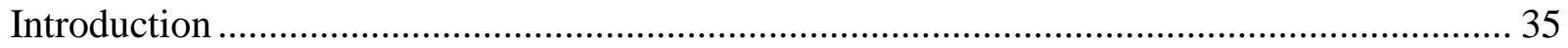




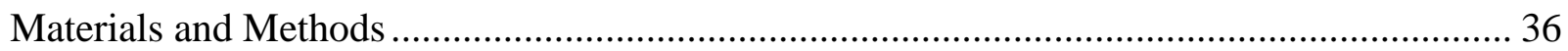

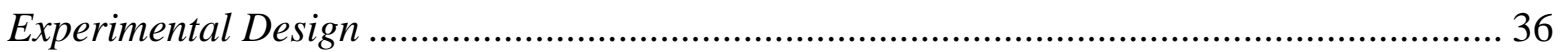

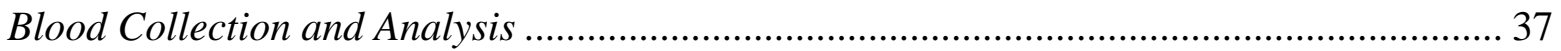

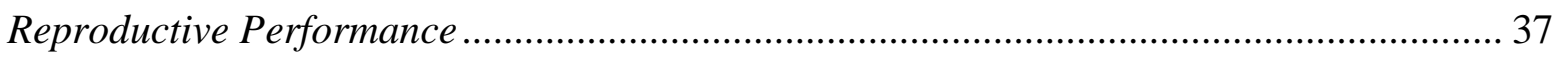

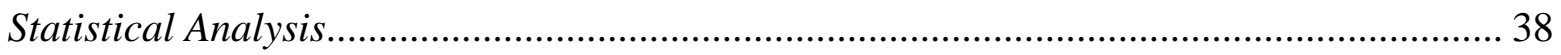

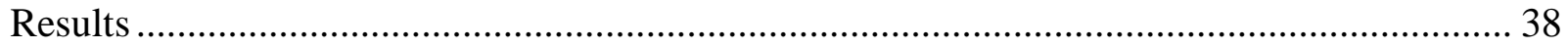

Serum Concentrations of Progesterone ............................................................................... 38

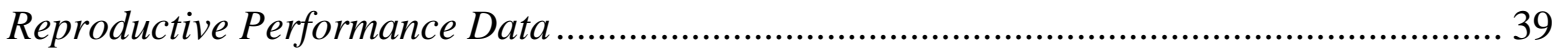

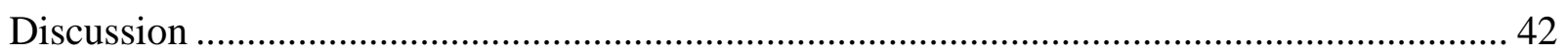

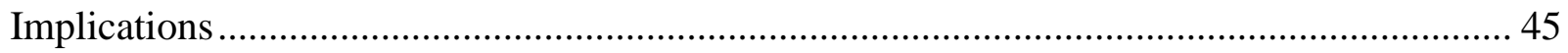

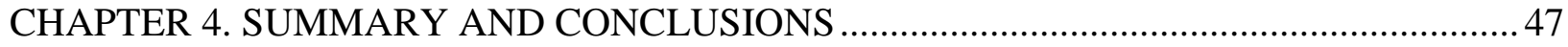

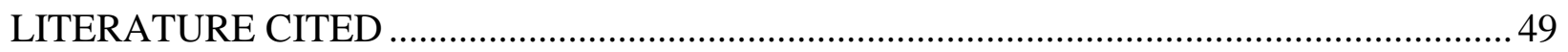




\section{LIST OF TABLES}

$\underline{\text { Table }}$

$\underline{\text { Page }}$

2.1. Reproductive performance of ewes after $5 \mathrm{~d}$ controlled internal drug releasing (CIDR) synchronization protocols administered during the transition period ............................... 30

3.1. Reproductive performance of ewes after $5 \mathrm{~d}$ controlled internal drug releasing (CIDR) synchronization protocols administered during the anestrous season ...........................42 


\section{LIST OF FIGURES}

$\underline{\text { Figure }}$

$\underline{\text { Page }}$

1.1. An illustrative representation of the changes in hormone levels throughout the estrous cycle of the ewe (Adapted from Caldwell et al., 1972) 3

2.1. Serum progesterone (P4) profiles before and after $5 \mathrm{~d}$ controlled internal drug releasing (CIDR) synchronization protocols administered during the transition period.

Treatments: $\mathrm{U}=$ untreated; $\mathrm{C}=\mathrm{CIDR}$ inserted on $\mathrm{d}-5$ and removed on $\mathrm{d} 0 ; \mathrm{P}=5 \mathrm{~d}$ CIDR and PG given at removal; $\mathrm{G}=\mathrm{GnRH}$ given on $\mathrm{d}-5,5 \mathrm{~d}$ CIDR and PG given at removal

2.2. Cumulative percentages of ewes that exhibited estrus per total ewes treated during the transition period in the various treatment protocols: $\mathrm{U}=$ untreated; $\mathrm{C}=\mathrm{CIDR}$ inserted on $\mathrm{d}-5$ and removed on $\mathrm{d} 0 ; \mathrm{P}=5 \mathrm{~d} \mathrm{CIDR}$ and $\mathrm{PG}$ given at removal; $\mathrm{G}=\mathrm{GnRH}$ given on $\mathrm{d}-5,5 \mathrm{~d}$ CIDR and $\mathrm{PG}$ given at removal

2.3. Cumulative percentages of ewes that lambed per ewes treated who were bred during the transition period to the various treatment protocols: $\mathrm{U}=$ untreated; $\mathrm{C}=\mathrm{CIDR}$ inserted on $\mathrm{d}-5$ and removed on $\mathrm{d} 0 ; \mathrm{P}=5 \mathrm{~d}$ CIDR and $\mathrm{PG}$ given at removal; $\mathrm{G}=$ GnRH given on $\mathrm{d}-5,5 \mathrm{~d}$ CIDR and PG given at removal.

3.1. Serum progesterone (P4) profiles before and after $5 \mathrm{~d}$ controlled internal drug releasing (CIDR) synchronization treatment protocols administered during the anestrous season. Treatments: $\mathrm{U}=$ untreated; $\mathrm{C}=\mathrm{CIDR}$ inserted on $\mathrm{d}-5$ and removed on $\mathrm{d} 0 ; \mathrm{P}=5 \mathrm{~d}$ CIDR and PG given at removal; $\mathrm{G}=\mathrm{GnRH}$ given on $\mathrm{d}-5,5 \mathrm{~d}$ CIDR and PG given at removal

3.2. Cumulative percentages of ewes that exhibited estrus per total ewes treated during the anestrous season in the various treatment protocols: $\mathrm{U}=$ untreated; $\mathrm{C}=\mathrm{CIDR}$ inserted on $\mathrm{d}-5$ and removed on $\mathrm{d} 0 ; \mathrm{P}=5 \mathrm{~d} \mathrm{CIDR}$ and $\mathrm{PG}$ given at removal; $\mathrm{G}=$ GnRH given on $\mathrm{d}-5,5 \mathrm{~d}$ CIDR and PG given at removal.

3.3. Cumulative percentages of ewes that lambed per ewes treated who were bred during the anestrous season to the various treatment protocols: $\mathrm{U}=$ untreated; $\mathrm{C}=\mathrm{CIDR}$ inserted on $\mathrm{d}-5$ and removed on d $0 ; \mathrm{P}=5 \mathrm{~d}$ CIDR and $\mathrm{PG}$ given at removal; $\mathrm{G}=$ GnRH given on $\mathrm{d}-5,5 \mathrm{~d}$ CIDR and $\mathrm{PG}$ given at removal. 


\section{LIST OF ABBREVIATIONS}

AP

Anterior Pituitary

cAMP .Cyclic AMP

C.

CIDR treated

CIDR

Controlled Internal Drug Releasing

CL Corpus Luteum

D. Day $(\mathrm{s})$

E2 Estradiol

eCG equine chorionic gonadotropin

FSH Follicle-stimulating hormone FDA. Food and Drug Administration FGA. Flurogestone acetate G. .Gonadotropin-releasing hormone treated GnRH Gonadotropin-releasing hormone

$\mathrm{H}$ Hour(s) hCG human chorionic gonadotropin IU International Units LH Luteinizing hormone

MAP Medroxyprogesterone acetate MGA Melengestrol Acetate $\mathrm{P}$ Prostaglandin treated P4 Progesterone PG Prostaglandin PMSG. Pregnant mare serum gonadotropin RIA Radioimmunoassay 
SCG. Superior cervical ganglia

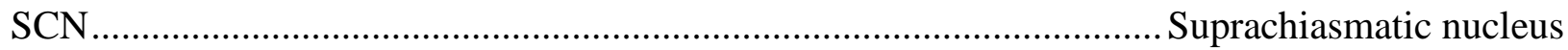

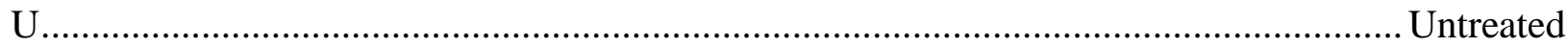
U.S. United States 


\section{CHAPTER 1. LITERATURE REVIEW \\ Introduction}

One of the largest factors having an impact on today's sheep industry that will ensure its future success and long-term sustainability is reproductive performance. The United States (U.S.) sheep industry is facing an exciting time with lamb and wool prices at an all-time high. However, for the U.S. sheep industry to remain competitive and to continue growing to meet the needs of consumers, it would be beneficial for producers to employ advanced reproductive technologies that improve efficiency and ultimately leading to an increase in their flock productivity. By doing so, producers will be able to enhance their operation's production in terms of percent lamb crop produced by a flock per year (National Research Council, 2008). To do so, a producer may potentially want to begin utilizing controlled internal drug releasing (CIDR) inserts, selecting for highly prolific ewes that are capable of breeding out-of-season, while culling ewes that don't produce twins.

To produce lambs consistently throughout the year in an accelerated lambing system, the use of exogenous hormones can be utilized in order to induce a synchronized estrus and stimulate cyclicity during the anestrous period. This can be achieved by either lengthening or reducing the duration of the estrous cycle by administration of exogenous progesterone (P4) or prostaglandin (PG). Gonadotropin-releasing hormone (GnRH) may also be incorporated into treatment protocols to assist in initiating hormonal events necessary to synchronize estrous cycles, such as estrus and ovulation, especially in anestrous ewes (Wildeus, 2000).

In 2009, the U.S. Food and Drug Administration (FDA) approved the CIDR for commercial use in sheep. The current label recommendation is to insert one CIDR per ewe for 5 days (d) with the intention of inducing estrus in ewes during the anestrous season (FDA, 2009). 
Therefore, the P4 inserts are referred to as $5 \mathrm{~d}$ CIDRs. This thesis focuses on examining the efficacy of the newly approved $5 \mathrm{~d}$ CIDR inserts for use in the commercial sheep industry during both the transition and anestrous seasons. The transition period (August through October) is the gradual change from the anestrous to estrous season, whereas the anestrous season (April through May) is when breeding typically does not occur. Prior to approval, common industry practice was to insert a CIDR, being used off label from New Zealand, for 12 to $14 \mathrm{~d}$ with or without an injection of gonadotropin (Rhodes and Nathanielsz, 1988; Carlson et. al, 1989; Wildeus, 2000; Abecia and Gonzalez-Bulnes, 2012).

In two studies by Knights et al. (2001a; 2001b), a 5 d CIDR treatment induced estrus in a greater proportion of seasonally anestrous ewes compared with untreated ewes. Addition of a PG injection at CIDR removal elicited a greater percentage of ewes observed in estrus and a greater lambing rate to the first service period, three days following CIDR removal, compared with ewes treated with PG alone (Dixon et al., 2006). Moreover, in a recent study, Titi et al. (2010) reported improvements in estrous synchronization and prolificacy with the inclusion of an injection of GnRH prior to insertion and PG at removal of intravaginal P4 impregnated sponges for $5 \mathrm{~d}$ during the breeding season. Limited research has been conducted utilizing the $5 \mathrm{~d}$ CIDR in combination with GnRH and PG in seasonally anestrous and estrous ewes.

Therefore, the following research focuses on synchronizing estrus in ewes during both the breeding and non-breeding seasons by potentially reducing the days to detected estrus, while increasing overall ewe prolificacy through the utilization of various $5 \mathrm{~d}$ CIDR protocols that include various combinations of the administration of GnRH and PG. 


\section{Reproduction in the Ewe}

The Estrous Cycle

A unique characteristic of sheep compared with cattle and swine is that the ovine specie is seasonally polyestrous between two distinct periods. Seasonally polyestrous females exhibit numerous estrous cycles that occur repeatedly only during a specific season of the year unless interrupted by pregnancy. A reproductive cycle consisting of predictable events, both behavioral changes and ovulation, which presents an opportunity for a female to become pregnant, is referred to as the estrous cycle (Senger, 2005). The estrous cycle begins at estrus and ends at the start of the ensuing estrus, lasting on average $17 \mathrm{~d}$ (Figure 1.1; Downey, 1980; Rosa and Bryant, 2003; Bartlewski et al., 2011).

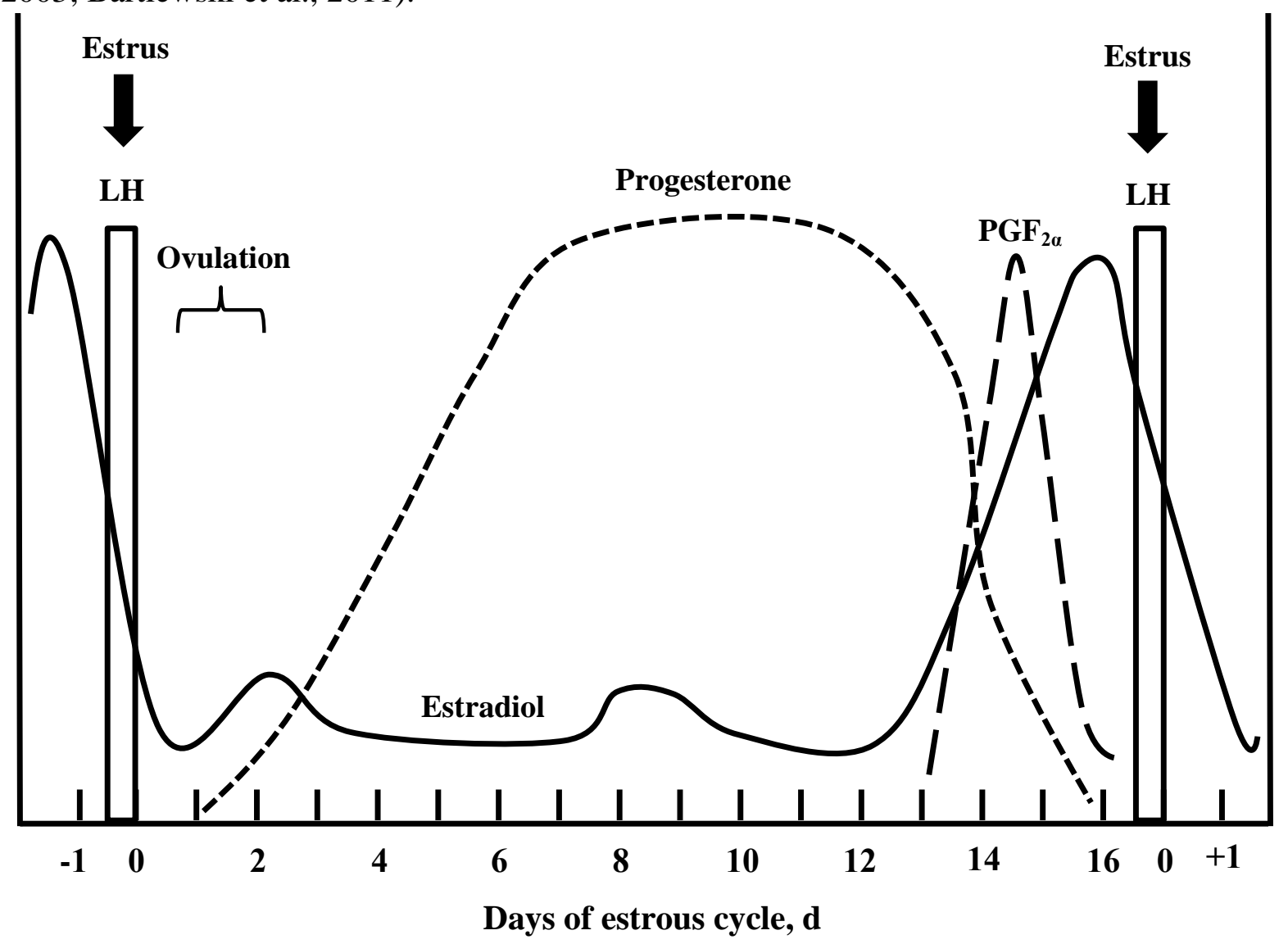

Figure 1.1. An illustrative representation of the changes in hormone levels throughout the estrous cycle of the ewe (Adapted from Caldwell et al., 1972). 
Two major phases comprise the estrous cycle; the follicular and luteal phases which represent 20 and $80 \%$ of the cycle, respectively. Each phase can be further divided into two stages each, with the follicular phase consisting of proestrus and estrus and the luteal phase consisting of metestrus and diestrus (McDonald, 1980). Follicular dynamics, which is the process of follicular growth and degeneration, occurs continually throughout the follicular phase, which lasts approximately 2 to $3 \mathrm{~d}$ (Gordon, 1997; Senger, 2005). The stage of proestrus which begins after luteolysis or destruction of the corpus luteum $(\mathbf{C L})$ in which P4 levels are declining, is characterized by elevated concentrations of estradiol (E2), due to growing follicles that are now the dominant ovarian structures. Release of follicle-stimulating hormone (FSH) from the anterior pituitary (AP) is responsible for inducing follicular growth. Due to elevated concentrations of E2, a luteinizing hormone $(\mathbf{L H})$ surge is experienced because of the positive feedback of E2 on the hypothalamus which releases a surge of GnRH which acts on the AP thus causing a surge of LH and hence ovulation occurs. The stage of estrus beginning at the cessation of proestrus and estrus or 'heat', $\mathrm{d} 0$ (Figure 1.1) of the estrous cycle, is the most visible event during this time. Estrus is the most recognizable behavioral change and is characterized by standing 'heat', a period in which the female is receptive to being bred (McDonald, 1980). The duration of estrus in the ewe typically lasts 30 hours (h) with ovulation occurring at 24 to $30 \mathrm{~h}$ after the onset of estrus (Downey, 1980; McDonald, 1980; Murdoch, 1985).

Ovulation brought about by the surge of LH during proestrus and estrus transition the ewe into the luteal phase (Gordon, 2004). The ewe undergoes spontaneous ovulation and therefore no cervical or vaginal stimulation is needed to induce ovulation; rather, ovulation is under hormonal control (Senger, 2005). Spanning ovulation and formation of the newly developed and functional CL is metestrus, occurring briefly for $2 \mathrm{~d}$. During this time, E2 
concentrations are decreasing and the newly ovulated follicle transforms into a CL and P4 concentrations are increasing quickly. Production of P4 and increases in concentrations of P4 are reflective of the growth and development of the CL as it becomes larger through the process of luteinization, cellular and structural remodeling. The last and longest stage (10 to $14 \mathrm{~d}$ ) to occur is diestrus. Diestrus occurs from the time the CL becomes functional and maximum secretion of P4 has been attained until luteolysis, structural and function degradation, of the CL. Peak levels of P4 are secreted around d 8 of the estrous cycle and concentrations are maintained until d 15 (McDonald, 1980; Gordon, 2004; Senger, 2005). The P4 being secreted by the CL is primarily responsible for regulating LH secretion (Abecia, 2011). If pregnancy does not occur, PG is secreted by the uterus in a pulsatile manner which will then cause regression of the CL. Due to a decrease in circulating concentrations of $\mathrm{P} 4$ at this time, another follicular phase will now be permitted to develop (Figure 1.1).

\section{Hormonal Control of the Estrous Cycle}

A variety of hormones are responsible for regulating the estrous cycle, all of which are produced primarily from four major systems of organs including the anterior and posterior lobes of the pituitary gland, the hypothalamus, ovary, and uterus. Of these, the hypothalamus plays a substantial role in neural regulation of the release of reproductive hormones. Melatonin stimulates the release of GnRH to bring about cyclicity in anestrous ewes (Senger, 2005). Gonadotropin-releasing hormone, a neurohormone that is synthesized and stored in the medial basal hypothalamus, is a decapeptide consisting of 10 amino acids, and provides the link between the neural and endocrine systems (Convey, 1973). Release of GnRH occurs in two different fashions depending on which of the two regions in the hypothalamus GnRH is being secreted. Two centers mediate the release of $\mathrm{GnRH}$, the tonic and surge centers. The tonic center is 
comprised of the ventromedial nucleus and the arcuate nucleus and is accountable for the basal secretion of GnRH. Through basal secretion, GnRH is released in very small pulses over an extended period of time at a constant and basal level. Through these small pulses of GnRH which act upon the anterior pituitary, the release of FSH and LH is stimulated. The growth and development of ovarian follicles are promoted by the stimulation of FSH and LH. In contrast, large doses of GnRH are secreted from the surge center in short bursts of high amplitude and frequency pulses. In order for GnRH to be released from the surge center, E2 concentrations must be high and $\mathrm{P} 4$ concentrations must be low. The surge center, is also referred to as the preovulatory center because it is responsible for the preovulatory release of GnRH. This preovulatory release of GnRH drives a surge release of LH, thus causing an ovulation (Hafez and Hafez, 2000; Senger, 2005).

Two glycoproteins released from the anterior pituitary, at or near the onset of estrus, are LH and FSH (Pant et al., 1977). The major luteotropic hormone in the ewe is LH and it is responsible for the release of the ovum after the wall of the follicle ruptures, while growth and maturation of the Graafian follicle is the primary duty of FSH (Hansel and Convey, 1983). By increasing adenylate cyclase and cyclic AMP (cAMP) the steroidogenic effects elicited by LH are able to be carried out on luteal tissues (Hansel and Convey, 1983). Hansel and Convey (1983) review the order of events pertaining to the feedback mechanism of LH. First, LH binds to its receptor which is located in the plasma membrane. This union activates adenylate cyclase and the production of cAMP occurs along with protein kinase activation. Following this, steroidogenic enzymes undergo phosphorylation as well as increased protein synthesis. Lastly, a segment of the bound LH is internalized and degraded, whereby secretory granules recycle LH receptors and incorporate them into the plasma membrane via exocytosis (Hansel and Convey, 
1983). Prior to ovulation, a preovulatory surge of LH and FSH occurs due to the positive feedback that increased concentrations of E2 have on the hypothalamus. This positive feedback mechanism causes a surge in GnRH which then releases LH and FSH. This surge in LH and FSH which typically lasts for 6 to $12 \mathrm{~h}$ is responsible for ovulation which occurs 24 to $30 \mathrm{~h}$ after peak gonadotropin levels (Hafez and Hafez, 2000).

During the preovulatory period, concentrations of E2 increase in both the ovarian venous blood (Baird and Scaramuzzi, 1976) and peripheral blood (Hansel et al., 1973), while reaching peak concentrations at estrus. While P4 concentrations are decreased in the preovulatory period, the increase in E2 clearly initiates the surge of GnRH, hence the release of LH and FSH and, consequently, ovulation (Hansel and Convey, 1983). In ewes, a preovulatory-like surge of LH is induced by the administration of exogenous E2 (Howland et al., 1971).

One of the most important hormones vital for a successful pregnancy in mammalian species is $\mathrm{P} 4$. Progesterone is crucial in regulating the establishment and maintenance of pregnancy along with various other reproductive events including uterine and mammary gland development and the process of ovulation. Additionally, P4 is integral for the implantation and maintenance of the embryo and inhibits smooth muscle contractions of the uterus (Leonhardt and Edwards, 2002).

Progesterone has a negative feedback on the hypothalamus. Elevated P4 concentrations reduce the basal episodic secretion of GnRH, therefore inhibiting the development of preovulatory follicles, the production of E2, estrus behavior and the preovulatory surge of GnRH and LH. The CL will maintain production of P4 throughout pregnancy if an embryo is present. Production of P4 by the CL begins approximately on $\mathrm{d} 4$ thereby marking the beginning of diestrus. Growth of the CL continues until maximal size and function has been obtained between 
7 and $14 \mathrm{~d}$. If pregnancy is not established, structural and functional degradation of the CL occurs on d 15 or 16, thus initiating a new estrous cycle to begin (Bazer et al., 1998).

Functioning as an endocrine organ, the uterine endometrium is responsible for producing PG which is a vasoconstrictor that causes luteolysis, or degeneration, of the CL if pregnancy is not established between d 15 and 16 post-estrus (Bazer et al., 1998). The main hormones responsible for the uterine release of $\mathrm{PG}$ are E2, P4, and oxytocin. The release of oxytocin is mediated by $\mathrm{P} 4$ and E2 by regulating endometrial oxytocin receptor expression in the endothelial lining. Synthesis of oxytocin is inhibited by P4 for 10 to $12 \mathrm{~h}$ and is known as the "progesterone block". Progesterone receptors decline though because the endometrium exhibits a negative feedback due to the continuous exposure to P4. Estrogen is then synthesized by the epithelium of the endometrium and released as $\mathrm{P} 4$ receptors decline. Oxytocin receptor expression is thus up-regulated due to the release of E2 and therefore the production and release of PG is achieved during the late luteal phase (Bazer et al., 1998). Developing antibodies that destroy oxytocin inhibit PG secretion, thus decreasing the production of the PG and increasing the duration of the luteal phase (Senger, 2005). Prostaglandin reaches the CL from the uterine vein by a vascular countercurrent exchange mechanism into the ipsilateral ovarian artery first suggested by McCracken et al. (1971). A high proportion of PG, without being diluted in the circulatory system, is sure to reach the ovary through this unique anatomical structure (Senger, 2005).

\section{Controlled Reproduction in the Ewe}

\section{Seasonality}

Sheep are often referred to as "short day" breeders because they begin to cycle and become sexually responsive when the amount of darkness increases in late summer to early autumn (Robinson and Karsch, 1988). The utilization of the photoperiod as a cue for breeding to 
occur is especially prevalent and more relied upon by sheep that are managed in colder and temperate climates located at latitudes greater than $30^{\circ}$ from the equator (Robinson and Karsch, 1988; Lincoln, 1992; Rosa and Bryant, 2003). In northern latitudes, sheep have been managed to breed in the fall, particularly mid-October through November in order to lamb in the spring or early summer (Robinson and Karsch, 1988). Lambing is ideal during this time because maximal growth and development of the offspring can be achieved while meeting the demands of the mother during lactation, all of which can be supported by optimal natural environmental conditions and forage production (Wayne et al., 1989). In a study conducted by Hulet et al. (1974) utilizing Rambouillet sheep, the estrous cycles of ewes located in the northwestern United States were compared to those of ewes in the southern United States. This study reported that ewes in the northwest had a greater duration of natural anestrous when compared with southern ewes (Hulet et al., 1974). Anestrous is a time during which the female is not receptive to being breed as she does not display a natural heat or exhibit regular estrous cycles during the spring and early summer months (Senger, 2005).

Photoperiod is one of the most important external factors that initiates the onset of the breeding season. The duration of the photoperiod is perceived by the amount of light that reaches the photoreceptors located on the retina (Abecia, 2011). Signals are then sent to a specific area of the rostral hypothalamus known as the suprachiasmatic nucleus (SCN) via a monosynaptic tract known as the retinohypothalamic tract. By regulating endogenous circadian rhythms, the SCN functions as an internal biological clock. The SCN is linked to the pineal gland by sympathetic innervation designated by the superior cervical ganglia (SCG; Lincoln, 1992; Rosa and Bryant, 2003). The pineal gland is responsible for facilitating the effects of photoperiod to bring about seasonal cyclicity by regulating the release of melatonin in a fashion 
that mimics a circadian rhythm. The release of melatonin occurs only at night and is positively correlated with the duration of darkness (Arendt et al., 1988; Karsch et al., 1988; Abecia, 2011). Melatonin stimulates the release of GnRH from the tonic center initiating the pulsatile release of LH thus promoting cyclicity (Senger, 2005).

Out-of-Season Breeding

Lambing occurs primarily at one time of the year since sheep are seasonally polyestrus. Therefore, the supply of lamb is concentrated during one part of the year in which most lamb is sold and ready for market at the same time. Due to the fluctuating availability of lamb, great variability in lamb prices occurs throughout the year, resulting in supply and demand of the season (National Research Council, 2008). Most lambs are born during winter and spring months, weaned in the summer and fall, and harvested 60 to $120 \mathrm{~d}$ after a finishing period. As a result, only a small portion of the U.S.'s lamb crop is born in the fall which creates a limited amount of fresh lamb for retail in the winter to early spring. Hence, the price of lamb increases greatly during this time. For producers to take advantage of this increase in out-of-season lamb, the industry needs to be able to effectively breed sheep during the anestrous season. By doing so, consumers will be able to enjoy lamb products more continuously throughout the year while producers are able to take advantage of labor, facilities, and upward price trends as well.

\section{The Ram Effect}

Producers can effectively advance the breeding season by stimulating ewes into estrus and ovulation to occur during the non-breeding season, through the ram effect which is inexpensive and easily applied. Anestrous ewes, isolated from rams for at least a month, will exhibit a synchronized heat after re-introduction to the male approximately one to one and a half 
estrous cycles (17 to $24 \mathrm{~d}$ ) later. This phenomenon has been termed the 'ram effect' and was first observed in sheep in the early 1940's (Underwood et al., 1944; Martin et al., 1986).

Some ewes may ovulate only once without visible estrus and then return to anestrous. Many ewes, though, ovulate twice without displaying estrus at each ovulation; however, if a CL develops in response to the second ovulation, the first fertile estrus is typically exhibited in conjunction with the third ovulation in response to the ram effect (Notter, 2002). The first induced LH surge causes an ovulation to occur without detectable estrus within 2 to $3 \mathrm{~d}$ of ram exposure and is of low fertility. If a CL does form from the first ovulation though, it typically regresses after 4 to $5 \mathrm{~d}$. Once regression has occurred, a second ovulation is induced and again no visible estrus is detectable. For estrus to accompany an ovulation, it is necessary for the ewe to be exposed to appropriate progesterone/progestagen dosages to release the ewe from the endocrine systems inhibitory feedback during anestrous. This 'priming' of the endocrine system needs to occur and once the body has been 'primed' short luteal phases will be prevented; hence, the CL will be able to be maintained for the full 14 d luteal phase (Schinckel, 1954; Martin et al., 1986; Perkins and Fitzgerald, 1994). The ram effect not only elicits a response through physical or visual contact but pheromones, produced by the ram that are present in the wool and/or wax of entire rams, can stimulate breeding activity in ewes transitioning out of anestrous (Watson and Radford,1960; Knight and Lynch, 1980).

Several variables exist when determining the impact the ram effect will have on anestrous ewes, one of those factors being the sexual behavior of the ram (Gordon, 1997). In a study conducted by Perkins and Fitzgerald (1994) in California, it was reported that a significantly greater percentage of ewes exposed to rams exhibiting a high level of sexual activity ovulated when compared with ewes exposed to low-activity rams (95\% vs. $78 \%$, respectively). 
The current status of the female is another vital component in regulating how successful the ram effect is going to be in regards to how deep in anestrous she is at the time of ram exposure (Cushwa et al., 1992). Response to the ram effect is greater in ewes as the start of the normal breeding season approaches. Cushwa (1992) documented a greater percentage of ewes responded to the ram effect in June than in May at $92 \%$ and $80 \%$, respectively.

The ram effect can also be used in conjunction with CIDR inserts to advance the breeding season and lambing. In a study conducted by Wheaton et al. (1992), during the breeding season $100 \%$ of ewes treated with a CIDR for $12 \mathrm{~d}$ exhibited estrus within $30 \mathrm{~d}$ after removal of the CIDR and $93 \%$ subsequently lambed from conception within the $30 \mathrm{~d}$ breeding period. Of the 59 ewes treated with a CIDR, 97\% exhibited estrus within $3 \mathrm{~d}$ of CIDR removal and $51 \%$ lambed. Of those ewes not treated with a CIDR, 95\% exhibited estrus and $84 \%$ lambed within the $30 \mathrm{~d}$ period following CIDR withdrawal. In the anestrous season of the same study, it was reported that $97 \%$ of ewes treated with a CIDR for $12 \mathrm{~d}$ exhibited estrus and $82 \%$ lambed from mating's during the specified $30 \mathrm{~d}$ period after CIDR removal. Of the 55 ewes treated with a CIDR, $89 \%$ exhibited estrus within $3 \mathrm{~d}$ of CIDR removal and $51 \%$ of those ewes lambed. Of the control ewes, $100 \%$ displayed estrus within the $30 \mathrm{~d}$ breeding period following CIDR removal and $100 \%$ of those ewes lambed within the $30 \mathrm{~d}$ breeding period.

\section{Estrous Synchronization}

\section{Progestins}

The primary role of $\mathrm{P} 4$, specifically when the female is pregnant, is to prevent the ewe from returning to estrus and ovulating. Synthetic derivatives of P4 are used to stimulate P4 production by the CL. Therefore, when the source of P4 is removed, concentrations of P4 are reduced, causing luteolysis, hence priming the ewe to return to estrus. Numerous methods are 
available for the exogenous delivery of P4; the most common of those being through the use of an intravaginal device that slowly releases $\mathrm{P} 4$, or oral feed additives.

\section{Flurogestone Acetate and Medroxyprogesterone Acetate}

Since the 1960s, the traditional method for synchronizing estrus in small ruminants during the breeding and anestrous seasons has been through the use of polyurethane sponges. The two common, highly potent progestagens that sponges are often infused with are Flurogestone acetate (FGA, 17 $\alpha$-Acetoxy-9-fluoro-113-hydroxypregn-4-ene-3, 20-dione) and Medroxyprogesterone acetate (MAP, 17 $\alpha$-Acetoxy-6 $\alpha$-methylpregn-4-ene-3, 20-dione). Sponges are inserted vaginally in the ewe, remain in place for $12 \mathrm{~d}$, and often a single dose of gonadotropin or pregnant mare serum gonadotropin (PMSG) is administered at removal of the device (Wildeus, 2000). The appropriate dose level of FGA in sponges lies in the range of 20 to $40 \mathrm{mg}$ and for MAP sponges the dose level employed is generally around 40 to $60 \mathrm{mg}$. Sponges, when inserted, should be placed as deep in the vagina as possible, up against the cervix with the sponge draw-strings clearly visible, for easy removal (Gordon, 1997 and 2004).

A study was conducted in anestrous Awassi ewes to determine the most appropriate form of P4 treatment with a sponge. Sponges were infused with $60 \mathrm{mg}$ MAP, $30 \mathrm{mg}$ FGA, and $40 \mathrm{mg}$ FGA and remained in place for $12 \mathrm{~d}$. At sponge removal and injection of 600 International Units (IU) of PMSG was administered. Husein and Kridli (2002) reported that all sponge applications (MAP, $30 \mathrm{mg}$ FGA, $40 \mathrm{mg}$ FGA and P4 sponges coupled with PMSG) were equally effective at inducing estrus. Ewes detected in estrus and overall lambing rate was similar $(P>0.1)$ among all treatment groups. 


\section{Melengestrol Acetate}

Developed in 1962, Melengestrol acetate (MGA, 6-methyl-17-alpha-acetoxy-16 methylene-pregn-4,6-diene-3,20-dione) is an orally active synthetic progestogen delivered via feed consumption and is used as a regimen for synchronizing estrus in sheep. Not only is MGA appealing in that it is affordable; but, MGA also offers several properties that make it practical to use as a synchronization tool, for it has the ability to promote endometrial proliferation, maintain pregnancy, and delay estrus activity. Although MGA was first marketed for the use in feedlot heifers to inhibit estrus, thereby improving feed efficiency and rate of gain, appropriate dosages have been adopted to control estrus and ovulation in seasonally anestrous ewes (Patterson et al., 1989).

The sheep industry has found that MGA fed typically at a rate of $0.125 \mathrm{mg}$ MGA per day, can be fed either once (Jabbar et al., 1994) or twice (Saffranski et al., 1992; Powell et al., 1996; Morrical et al., 1997; Daniel et al., 2001) per day, just prior to breeding for a period of 8 to $14 \mathrm{~d}$. One of the major drawbacks to the administration of MGA has been the documented reduction in fertility. Ewe fertility has ranged from 48 to $61 \%$ of ewes coming into a synchronized estrus up to $10 \mathrm{~d}$ after the last feeding of MGA with the greatest fertility coming after only $4 \mathrm{~d}$ of treatment (Jabbar et al., 1994; Powell et al., 1996).

In cattle, after the last feeding of MGA, the average interval to estrus or ovulation ranged from 3 to $7 \mathrm{~d}$ (Patterson et al., 1989). In numerous studies involving cattle treatments utilizing progestagens reduced fertility at the estrus immediately after treatment, especially if fed for more than $14 \mathrm{~d}$; however, not at any subsequent estrus that followed (Patterson et al., 1989). Despite this concern, at the end of the regular breeding season, cattle on MGA treatment had pregnancy rates greater than or equal to controls (Patterson et al., 1989). In contrast, Powell et al. (1996), 
reported in sheep that the duration of feeding MGA $(0.25 \mathrm{mg} / \mathrm{ewe} / \mathrm{d}$ for 8,11 , or $14 \mathrm{~d})$ did not affect the interval from the last feeding to estrus, the proportion of ewes lambing per ewe exposed, or lambs born per ewe lambing. Melengestrol acetate can also be used in conjunction with gonadotropins (Saffranski et al., 1992; Jabbar et al., 1994; Powell et al., 1996; Morrical et al., 1997).

\section{Gonadotropins}

Gonadotropins are often coupled with P4 treatments aimed at synchronizing estrus to initiate ovulation and enhance fertility in anestrous ewes. The most popular gonadotropin used is P.G. 600 (Wildeus, 2000). Commercially available P.G. 600, which is only approved for the use in swine to induce estrus in pubertal gilts, contains $400 \mathrm{IU}$ of equine chorionic gonadotropin (eCG) and 200 IU of human chorionic gonadotropin (hCG) per $5 \mathrm{~mL}$ and is often used in sheep at the $5 \mathrm{~mL}$ does level recommended for swine in combination with MGA treatment (Wildeus, 2000).

A variety of outcomes have been reported with the use of P.G. 600. Safranski et al. (1992) documented that P.G. 600 when coupled with an MGA treatment lasting $10 \mathrm{~d}$ had no beneficial effects on conception rate and number of lambs born per ewe. In contrast, when $5 \mathrm{~mL}$ of P.G. 600 was injected at the end of a $10 \mathrm{~d}$ MGA treatment, a 20\% increase in conception rate was reported by Morrical et al. (1997) in ewes receiving the combination treatment and controls compared with ewes receiving MGA only. Windorski et al. (2008) reported an increase in the percentage of ewes mated during the first $6 \mathrm{~d}$ of the breeding season in MGA and MGA + P.G. 600 treated ewes when compared with control and the interval from ram introduction to lambing was decreased in MGA treated ewes (approximately $166 \mathrm{~d}$ ) than control ewes (171 d). In the 
same study by Windorski et al. (2008), a greater proportion of ewes fed MGA (18\%) lambed to a synchronized estrus when compared to control ewes (2.0\%).

P.G. 600 has been shown to increase ovulation rate in Hampshire, Rambouillet, and FinnDorset-Rambouillet crossbred ewes from 1.79 CL/ewe in control ewes to 2.32 CL/ewe in ewes treated with MGA and P.G. 600; however, ewes receiving P.G. 600 only, had significantly reduced mating rates $(6.6 \%)$ when compared to ewes receiving both MGA and P.G. 600 (69.8\%, Safranski et al., 1992). Ovulation rate can be increased through the administration of P.G. 600 but it needs to be used in conjunction with a progestagen treatment to induce estrus in ewes.

\section{Prostaglandins}

Prostaglandins are vital in regulating reproduction in female livestock. Prostaglandins play essential roles in ovulation, luteal function, maternal recognition of pregnancy, implantation and maintenance of gestation. Exogenous prostaglandins have been used in conjunction with progestins, estrogens, and GnRH to assist in the synchronization of estrus (Weems et al., 2006). Prostaglandin increases pituitary responsiveness to GnRH to release LH (Randel et al., 1996) and the main role of PG during the estrous cycle is termination of the luteal phase through luteolysis. The ewe will return to estrus and ovulate after regression of the CL. Prostaglandins therefore are only effective on cyclic females who have an active CL. Prostaglandin can have an effect on the CL from d 4 of the estrous cycle to the day of natural luteolysis (Hackett and Robertson, 1980). Thus, it is ideal to administer 2 injections of PG, 9 to $10 \mathrm{~d}$ apart. This will ensure that most of the ewes will be in mid-luteal phase at the time of the second injection and therefore will respond with estrus behavior and ovulation. Hence, ewes in anestrous or in early or late luteal or follicular phase at the time of administration of PG will not respond (Abecia et al., 2011 and 2012). 
In a study comparing the use of CIDRs coupled with a PG injection given twice, $3 \mathrm{~h}$ apart $1 \mathrm{~d}$ before CIDR removal or PG administered twice, $3 \mathrm{~h}$ apart after CIDR removal and PG administered alone, it was reported that ewes receiving a CIDR and PG together exhibited a greater estrus response, greater pregnancy rate to the first service, and a greater lambing rate to the first service period than those ewes receiving a PG injection alone (Dixon et al., 2006). This illustrates that the use of PG along with a CIDR is more effective at bringing ewes into a synchronized estrus versus when used alone.

\section{Controlled Internal Drug Releasing Inserts}

The CIDR dates back to 1981 upon its development by the AHI Plastic Moulding Company, Hamilton, in conjunction with the Ministry of Agriculture \& Fisheries in New Zealand (Wheaton et al., 1993). A CIDR insert is composed of silicone molded over a flexible nylon spine with a tail protruding from the core and is infused with $0.3 \mathrm{~g}$ of exogenous $\mathrm{P} 4$ and is to be inserted vaginally (Wheaton et al., 1993).

Intravaginal CIDRs are utilized on commercial sheep operations as a controlled reproductive management tool. After withdrawal of the CIDR, a surge of gonadotropin from the AP is likely to occur and is sufficient to induce estrus at least $36 \mathrm{~h}$ after ram exposure and therefore a producer is able to synchronize their flock for the breeding season (Van Cleeff et al., 1998).

Traditional industry practice has been to insert a CIDR for 12 to $14 \mathrm{~d}$ (normal luteal phase) with or without an injection of gonadotropin at removal (Rhodes and Nathanielsz, 1988; Carlson et. al, 1989; Wildeus, 2000; Abecia and Gonzalez-Bulnes, 2012). During the anestrous season an injection of gonadotropin is often administered at CIDR removal because sufficient amounts of gonadotropin appear to be unavailable to initiate the required preovulatory events 
necessary to bring about estrus and ovulation (Gordon, 1997). Serum P4 concentrations have been found to increase rapidly after CIDR insertion, levels peak after $3 \mathrm{~d}$ and serum concentrations of P4 begin to decline gradually thereafter (Ainsworth and Downey, 1986; Wheaton et al., 1993). Hamra et al. (1986) reported similar findings after treatment with CIDRs for $13 \mathrm{~d}$ in which $\mathrm{P} 4$ concentrations increased to near maximum levels within $24 \mathrm{~h}$, reached peak levels $4 \mathrm{~d}$ after insertion and then declined gradually. Keeping in mind the CL produces P4 throughout its lifespan (10 to $14 \mathrm{~d})$; no treatment protocols are recommended over $14 \mathrm{~d}$. However, some studies utilizing CIDRs for as few as $5 \mathrm{~d}$ have achieved similar results when compared to leaving the CIDR in for 12 to $14 \mathrm{~d}$ (Knights et al., 2001a and 2001b).

It has been reported that ewes receiving a CIDR for $14 \mathrm{~d}$, when compared with those treated with a MAP sponge, showed estrus earlier and with closer synchrony (Rhodes and Nathanielsz, 1988). Of those ewes receiving CIDR treatment, 80\% came into estrus $1 \mathrm{~d}$ after CIDR removal compared with $41 \%$ of ewes treated with a MAP sponge. In contrast, Hamra et al. (1989) reported no significant differences were found between ewes treated with FGA sponges and a CIDR.

Another study comparing CIDRs and MAP sponges that were in place for $12 \mathrm{~d}$ with an injection of eCG (500 IU) at removal of the pessary device, reported no differences in the percentage of ewes in detected estrus (93.3 and 100\%) and the duration from the end of treatment to the onset of estrus $(30.1 \pm 7.6 \mathrm{~h}$ and $29.6 \pm 5.6 \mathrm{~h})$ in ewes treated with a CIDR or MAP sponge, respectively (Hashemi et al., 2006). Godfrey et al. (1999) reported an estrous response of $100 \%$ and $94.4 \%$ in ewes treated with a CIDR or by a P4 sponge without eCG contrary to the findings in the previous study by Hashemi et al. (2006). 
Many studies have shown the use of FGA and MAP sponges and CIDRs are relatively equally effective in synchronizing estrus; however, many producers prefer utilization of the CIDR. The first reason is that it is not necessary to break the hymen prior to insertion of a CIDR, as it needs to be done if sponges are to be utilized. This is a great advantage for it reduces the potential of infection and vaginal adhesions that may occur (Romano, 2004). Additionally, vaginal mucous secretions are often released upon the removal of sponges and are accompanied by a potent, foul smell making sponges less aesthetically pleasing to handle when compared to CIDRs in which vaginal fluid discharge is reduced (Carlson et al., 1989, Romano, 2004).

Wheaton et al. (1993) reported $74 \%$ of ewes treated with a CIDR to synchronize estrus during the breeding season, lambed within a $6 \mathrm{~d}$ period and another $20 \%$ lambed $16 \mathrm{~d}$ later. Daniel et al. (2000) found ewes treated with a CIDR for $8 \mathrm{~d}$ had decreased days to estrus and a greater percentage of CIDR treated ewes lambed at parturition when compared with control ewes. During the breeding season, Carlson et al. (1989) reported when CIDRs were left in place for $12 \mathrm{~d}, 91 \%$ of ewes were bred $5 \mathrm{~d}$ post CIDR removal and $67 \%$ lambed in response to matings within $5 \mathrm{~d}$. Overall, $92 \%$ of ewes lambed in the current study, compared with the spontaneous fall breeding for these flocks $(95 \%)$.

In two studies by Knights et al. (2001a; 2001b), a 5 d CIDR treatment was found to stimulate an effective estrous response in seasonally anestrous ewes compared with control ewes. In another study conducted by Knights et al. (2003), approximately $72 \%$ of ewes treated with a 5 d CIDR came into estrus. A $51 \%$ pregnancy rate was obtained and a 58\% and $80 \%$ lambing rate to the first service and both services were achieved, respectively. These two studies helped validate and aid in the approval of CIDR inserts which were recently sanctioned for use in sheep 
by the U.S. FDA in 2009 (FDA, 2009). The label instructions state one CIDR is to be inserted vaginally per ewe for $5 \mathrm{~d}$ to induce estrus in anestrous ewes (FDA, 2009).

Since research pertaining to the 5 d CIDR following the products approval in 2009 for use in commercial sheep operations is limited, the aims of the following experiments have been designed to determine the efficacy of the $5 \mathrm{~d}$ CIDR at inducing estrus during both the estrous and anestrous seasons and the impact these protocols have on ewe reproductive performance. 


\title{
CHAPTER 2. ESTROUS SYNCHRONIZATION IN SHEEP USING GONADOTROPIN- RELEASING HORMONE, PROSTAGLANDIN, AND CONTROLLED INTERNAL DRUG RELEASE INSERTS
}

\begin{abstract}
The objective of this two year study was to evaluate the effects of combinations of controlled internal drug releasing (CIDR) inserts infused with progesterone (P4) in association with prostaglandin (PG), and gonadotropin-releasing hormone (GnRH) on the reproductive performance of Columbia and Hampshire ewes ( $\mathrm{n}=76$ and 100, respectively) after synchronization of estrus during the transition period (August). Ewes were randomly assigned to 1 of 3 periods 1 week apart and then were randomly assigned to 1 of 4 treatments; 1) Untreated $(\mathbf{U}, \mathrm{n}=44) ; 2) 5 \mathrm{~d}$ CIDR $(0.3 \mathrm{~g} \mathrm{P} 4)$ insert $(\mathbf{C}, \mathrm{n}=45) ; 3) 5 \mathrm{~d}$ CIDR and PG (dinoprost, $10 \mathrm{mg}$ i.m.) at CIDR removal (P, $\mathrm{n}=43$ ); and 4) GnRH (gonadorelin, $0.02 \mathrm{mg}$ i.m.) at CIDR insertion (remained in place for $5 \mathrm{~d}$ ) and PG at CIDR removal $(\mathbf{G}, \mathrm{n}=44)$. Rams equipped with marking harnesses were introduced at CIDR removal (d 0) and ewes were checked at $0800 \mathrm{~h}$ and $1700 \mathrm{~h}$ daily for breeding marks starting on d 0 . Blood samples were collected via jugular venipuncture on $\mathrm{d}-12,-5,0,1,2,3,4,5,6,8,10,11,12,14,17$ and 20 . Serum was analyzed for P4 concentrations via radioimmunoassay (RIA). Data collected included: days to estrus, days to lambing, percentage of ewes exhibiting estrus, pregnancy rate, lambing rate, and prolificacy. A treatment $\times$ time interaction $(P \leq 0.05)$ was present for concentrations of P4. Untreated ewes had greater $(P \leq 0.01)$ concentrations of $\mathrm{P} 4$ compared with $\mathrm{C}$ on $\mathrm{d} 3$ and $4, \mathrm{C}$ and $\mathrm{G}$ on $\mathrm{d} 5$, and $\mathrm{P}$ and $\mathrm{G}$ on $\mathrm{d} 6$. Overall days to estrus were greater $(P \leq 0.01)$ in $\mathrm{U}(9.7 \pm 1.12 \mathrm{~d})$ and $\mathrm{P}(6.5 \pm 1.05 \mathrm{~d})$ compared with $\mathrm{C}(3.6 \pm 1.03 \mathrm{~d})$. The proportion of ewes exhibiting estrus within $7 \mathrm{~d}$ post ram introduction, the first service period, was greater $(P \leq 0.01)$ in all treatments receiving a CIDR
\end{abstract}


compared with $\mathrm{U}$. Pregnancy rate within $7 \mathrm{~d}$ post CIDR removal was greater $(P=0.02)$ for $\mathrm{C}, \mathrm{P}$, and $\mathrm{G}(37 \%, 15$ of $45 ; 36 \%, 15$ of 43 , and $28 \%, 12$ of 44 , respectively) compared with $\mathrm{U}(0 \%, 0$ of 44). Lambing rate to the first service period was greater $(P=0.02)$ in $\mathrm{C}$ and $\mathrm{P}$ ewes compared with $\mathrm{U}$, and $\mathrm{G}$ being intermediate. No differences $(P \geq 0.17)$ were detected in pregnancy and lambing rate overall and prolificacy to the first and overall service periods. In conclusion, all ewes receiving a $\mathrm{CIDR}$ treatment $(\mathrm{C}, \mathrm{P}$, or $\mathrm{G})$ came into estrus more quickly than untreated ewes. The proportion of ewes exhibiting estrus and pregnancy to the first service period was also greater in those ewes receiving any CIDR treatment compared with untreated ewes.

\section{Introduction}

In sheep, variability of hormone levels and time of ovulation occurs in females; hence efficacy in regards to various estrous synchronization protocols has been challenging to achieve (Dutt, 1953). Several strategies for synchronization in sheep have included providing exogenous progesterone (P4) to extend the luteal phase or the administration of prostaglandin (PG) to shorten the luteal phase by causing regression of the corpus luteum (CL) (Wildeus, 2000). In addition, estrus can be initiated in a portion of seasonally anestrous ewes after exposure to synthetic progestins and/or rams. Effective ewe synchronization protocols could offer numerous advantages to both consumers and producers by production of a more continuous supply of lamb throughout the year and reduction of the overall breeding and lambing season(s) to reduce labor, feed, and facilities (Carlson et al., 1989).

Current industry practice when using the controlled internal drug releasing (CIDR) insert as an estrous synchronization tool is to administer the insert for 12 to $14 \mathrm{~d}$. Some protocols also suggest an injection of gonadotropin after removal for improved estrus synchronization (Rhodes 
and Nathanielsz, 1988; Carlson et. al, 1989; Wildeus, 2000; Abecia and Gonzalez-Bulnes, 2012). In 2009, CIDR inserts were approved for use in sheep by the Food and Drug Administration (FDA) and labeled for $5 \mathrm{~d}$ to induce estrus in seasonally anestrous ewes (FDA, 2009).

It has been reported that CIDR insertion for a $5 \mathrm{~d}$ period was equally effective at stimulating an estrus response in seasonally anestrous ewes compared with ewes treated with a $12 \mathrm{~d}$ CIDR (Knights et al., 2001a). Moreover, when the CIDR was used in combination with PG, a greater proportion of ewes were observed in estrus and a greater lambing rate to the first service period was achieved compared with ewes treated with PG alone (Dixon et al., 2006). Additionally, GnRH given prior to a 5 d treatment of exogenous P4 via a sponge and PG administered at removal was an effective synchronization protocol that improved prolificacy during the breeding season (Titi et al., 2010). We hypothesized ewes receiving a $5 \mathrm{~d}$ CIDR treatment will express more synchronized estrus and have an increase in reproductive performance compared with untreated ewes. The objective of the current study was to evaluate the effects of CIDRs administered for $5 \mathrm{~d}$, GnRH, and PG on the reproductive performance of sheep during the transition period from anestrous to estrous.

\section{Materials and Methods}

The North Dakota State University Institutional Animal Care and Use Committee approved all procedures involving animals used in this research, IACUC \#A11007.

\section{Experimental Design}

In August 2010 and 2011, at the North Dakota State University Sheep Unit in Fargo, ND, Columbia $(n=76)$ and Hampshire $(n=100)$ ewes were randomly assigned to treatment and period to examine estrus synchronization protocols applied to ewes prior to fall seasonal estrus cyclicity. Three periods, 1 week apart, were used to control for effect of season. One week prior 
to treatment application, ewes were moved to paddocks that had not been previously grazed for one month. Prior to treatment administration, all ewes were moved to a drylot and fed alfalfa hay (3 kg/ewe) and a $14 \%$ crude protein concentrate ration (1 kg/ewe) daily.

Ewe estrous synchronization treatments were: 1) Untreated (U, $\mathrm{n}=44) ; 2) 5 \mathrm{~d}$ CIDR insert (EAZI-BREED CIDR Sheep Insert, 0.3 g P4, Pfizer Animal Health, New York, NY;C, n = 45); 3) $5 \mathrm{~d}$ CIDR and PG (Lutalyse, $10 \mathrm{mg} / \mathrm{mL}$ dinoprost tromethamine i.m., Pfizer Animal Health, New York, NY) at CIDR removal (P, n = 44); and 4) GnRH (Factrel, 0.02 mg/mL gonadorelin hydrochloride i.m., Pfizer Animal Health, New York, NY) at CIDR insertion and PG at removal $(\mathbf{G}, \mathrm{n}=43)$. Ewes were single sire mated at a ewe to ram ratio equal to or less than 25:1. Rams equipped with marking harnesses were introduced to ewes at CIDR removal (d 0 ) and $U$ ewes were also exposed to rams at this time. Ewes were checked twice daily for breeding marks (detected estrus) at $0800 \mathrm{~h}$ and $1700 \mathrm{~h}$ starting on $\mathrm{d} 0$. Ewes remained with rams for at least $60 \mathrm{~d}$.

\section{Blood Collection and Analysis}

To evaluate P4 concentration levels, blood samples were collected via jugular venipuncture into $10 \mathrm{~mL}$ serum tubes (BD Vacutainer Serum, Becton, Dickinson and Company, Franklin Lakes, NJ) and immediately placed on ice. Samples were centrifuged at $4^{\circ} \mathrm{C}$ for $30 \mathrm{~min}$ at $1,500 \mathrm{x}$ g and serum was transferred into plastic $2.0 \mathrm{~mL}$ microcentrifuge tubes and frozen at $20{ }^{\circ} \mathrm{C}$ until assayed. Blood samples were collected 1 week prior to $(\mathrm{d}-12)$ and on the day of treatment initiation ( $\mathrm{d}-5)$ to obtain baseline concentrations of P4. Further samples were collected at CIDR removal (d 0) and on d 2, 4, 6, 8, 10, and 12 in 2010 and on d 1, 2, 3, 4, 5, 8, $11,14,17$, and 20 in 2011. To detect circulating P4 in serum, samples were assayed using a solid-phase, no extraction RIA (Coat-a-Count Progesterone, Diagnostic Products Corporation, 
Los Angeles, CA; Stevenson et al., 2011). The assay kit was validated for ovine serum using an assay volume of $100 \mu \mathrm{l}$ (Hamra et al., 1986; Schneider and Hallford, 1996). Assay tubes for the standard curve contained $0.1,0.25,0.5,1.0,2.0,5.0,10.0$, and $20 \mathrm{ng} / \mathrm{ul}$. Assay sensitivity for a 100- $\mu 1$ sample was $0.1 \mathrm{ng} / \mathrm{mL}$. Ewes were determined to be cycling if serum P4 concentrations were greater than $1 \mathrm{ng} / \mathrm{mL}$ on either or both the $\mathrm{d}-12$ or -5 samples. All samples for a single ewe were ran within the same assay and treatments were run in a random order. The intra- and inter-assay CVs were $5.39 \%$ and $3.61 \%$, respectively.

\section{Reproductive Performance}

Data collected included: days to estrus, days to lambing, percent ewes exhibiting estrus, pregnancy rate, lambing rate, and prolificacy. The latter four measures of interest were classified as either to the first service period which is defined as $7 \mathrm{~d}$ post CIDR removal or overall beginning from $\mathrm{d} 0$ until ram removal. The number of ewes marked by a ram as a percentage of all ewes on study was represented by the percent of ewes exhibiting estrus. The number of ewes lambing as a percentage of ewes in all treatments was denoted as pregnancy rate and the number of lambs born per ewe exposed to rams is represented by lambing rate. Lastly, the number of lambs born per ewe lambing is represented as prolificacy.

\section{Statistical Analysis}

Repeated measures of the MIXED procedure of SAS (SAS Inst., Inc., Cary, NC) were used to analyze serum concentrations of P4. Main effects of the model included treatment, time, cycling status, and treatment $\times$ time interaction. The MIXED procedures of SAS were utilized to examine days to detected estrus and days to lambing. The model included the main effects of treatment, breed, age cycling status, and all possible interactions. The GLIMMIX procedures of SAS were used to analyze percent ewes exhibiting estrus, pregnancy rate, lambing rate, and 
prolificacy. The model included the main effects of treatment, breed, age, cycling status, and their respective interactions. To compare all CIDR treatment groups against untreated ewes, contrast statements were run on days to estrus, days to lambing, percent ewes exhibiting estrus, pregnancy rate, lambing rate and prolificacy to both the first service period and overall. Data are presented as least squares means and treatment differences were considered significant at $P \leq$ 0.05. Interactions with a $P$-value $>0.20$ were removed from the model.

\section{Results}

\section{Serum Concentrations of Progesterone}

A treatment $\times$ time interaction $(P \leq 0.05$; Figure 2.1$)$ was present for concentrations of P4. At CIDR insertion $(\mathrm{d}-5), \mathrm{G}$ had greater $(P \leq 0.01)$ concentrations of $\mathrm{P} 4$ compared with $\mathrm{C}$ and P. All treatments receiving a CIDR insert had greater $(P \leq 0.01)$ concentrations of $\mathrm{P} 4$ at CIDR removal (d 0) compared with $\mathrm{U}$. Untreated ewes had greater $(P \leq 0.01)$ concentrations of P4 compared with $\mathrm{C}$ on d 3 and 4, $\mathrm{C}$ and $\mathrm{G}$ on d 5, and P and $\mathrm{G}$ on d 6. On d 8, U had lower (P $\leq 0.03$ ) concentrations compared with $\mathrm{C}$. On d 12, U had lower concentrations of P4 compared with $\mathrm{C}, \mathrm{P}$, and $\mathrm{G}$ whereas $\mathrm{P}$ had greater $(P \leq 0.01)$ concentrations compared with $\mathrm{C}$. Lastly, on $\mathrm{d}$ 17, $\mathrm{U}$ had greater $(P \leq 0.02)$ concentrations of $\mathrm{P} 4$ compared with $\mathrm{P}$ and $\mathrm{G}$, and $\mathrm{P}$ had greater $(P \leq$ 0.04) concentrations of P4 compared with $\mathrm{C}$.

\section{Reproductive Performance Data}

Overall days to estrus after CIDR removal was greater $(P \leq 0.01$; Table 2.1$)$ in $U(9.7 \pm$ $1.12 \mathrm{~d})$ and $\mathrm{P}(6.5 \pm 1.05 \mathrm{~d})$ compared with $\mathrm{C}(3.6 \pm 1.03 \mathrm{~d})$ whereas $\mathrm{G}$ was intermediate $(6.2 \pm$ $1.06 \mathrm{~d})$. Similarly, ewes receiving any CIDR treatment (C, P, or G, $6.52 \pm 1.06 \mathrm{~d})$ expressed estrus sooner $(P=0.01)$ after ram introduction than untreated ewes $(9.68 \pm 1.12 \mathrm{~d})$. Overall days to lambing were not different $(P \leq 0.01$; Table 2.1) among the treatments. Additionally, no 
differences $(P \leq 0.10)$ were detected for days to lambing in ewes receiving any of the CIDR treatments compared with untreated ewes. The proportion of ewes exhibiting estrus during the first service period was the least $(P=0.01$; Table 2.1) in U compared to all CIDR treated ewes; however, no differences $(P=0.17)$ were detected for percent ewes exhibiting estrus between CIDR treated ewes and untreated ewes during the entire breeding season. Moreover, no differences $(P>0.34)$ were detected among CIDR treated ewes for estrus rate during the first 7 days and the entire breeding season. Pregnancy rate within $7 \mathrm{~d}$ post CIDR removal was greater $(P=0.02$; Table 2.1) for ewes receiving a CIDR (32\%, 42 of 132) compared with untreated ewes (0\%, 0 of 44). No difference $(P \geq 0.40)$ in pregnancy rate to the first service period was detected among $\mathrm{C}, \mathrm{G}$, and $\mathrm{P}$ treated ewes. Lambing rate to the first service period was greater $(P=0.02$; Table 2.1) in all CIDR treated ewes (33\%, 43 of 132) compared to untreated ewes ( $0 \%, 0$ of 44$).$ No differences $(P \geq 0.31$; Table 2.1$)$ were detected among treatments for overall pregnancy rate, lambing rate, or prolificacy. 


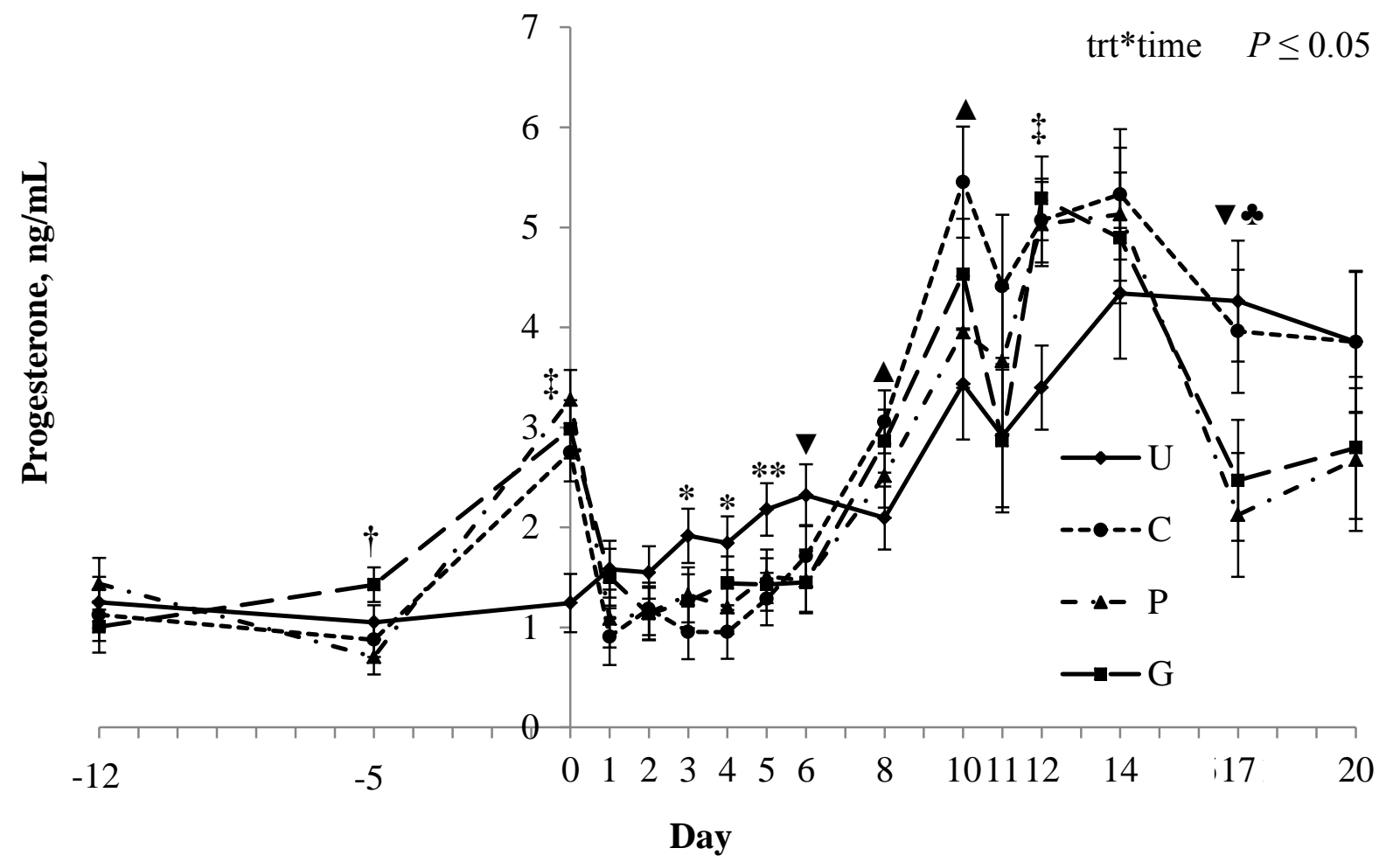

Figure 2.1. Serum progesterone (P4) profiles before and after $5 \mathrm{~d}$ controlled internal drug release (CIDR) synchronization protocols administered during the transition period. Treatments: $\mathrm{U}=$ untreated; $\mathrm{C}=\mathrm{CIDR}$ inserted on $\mathrm{d}-5$ and removed on $\mathrm{d} 0 ; \mathrm{P}=5 \mathrm{~d}$ CIDR and $\mathrm{PG}$ given at removal; $\mathrm{G}=\mathrm{GnRH}$ given on $\mathrm{d}-5,5 \mathrm{~d}$ CIDR and $\mathrm{PG}$ given at removal. A treatment $\times$ day interaction was detected $(P \leq 0.05) . \dagger=\mathrm{G}$ had greater concentrations of $\mathrm{P} 4$ compared with $\mathrm{C}$ and $\mathrm{P}$ on $\mathrm{d}-5(P \leq 0.05) . \$=\mathrm{C}, \mathrm{P}$, and $\mathrm{G}$ had greater concentrations of $\mathrm{P} 4$ compared with $\mathrm{U}$ on $\mathrm{d}$ 0 and $12(P \leq 0.05) . *=\mathrm{C}$ had lower concentrations of $\mathrm{P} 4$ compared with $\mathrm{U}$ on $\mathrm{d} 3$ and $4(P \leq$ $0.05) . * *=\mathrm{C}$ and $\mathrm{G}$ had lower concentrations of $\mathrm{P} 4$ compared with $\mathrm{U}$ on $\mathrm{d} 5(P \leq 0.05) . \quad \nabla=\mathrm{P}$ and $\mathrm{G}$ had lower concentrations of $\mathrm{P} 4$ compared with $\mathrm{U}$ on $\mathrm{d} 6$ and $17(P \leq 0.05) . \quad \Delta=\mathrm{C}$ had greater concentrations of $\mathrm{P} 4$ compared with $\mathrm{U}$ on $\mathrm{d} 8$ and $10(P \leq 0.05)$. $=\mathrm{C}$ had greater concentrations of $\mathrm{P} 4$ compared with $\mathrm{P}$ on $\mathrm{d} 17(P \leq 0.05)$. 


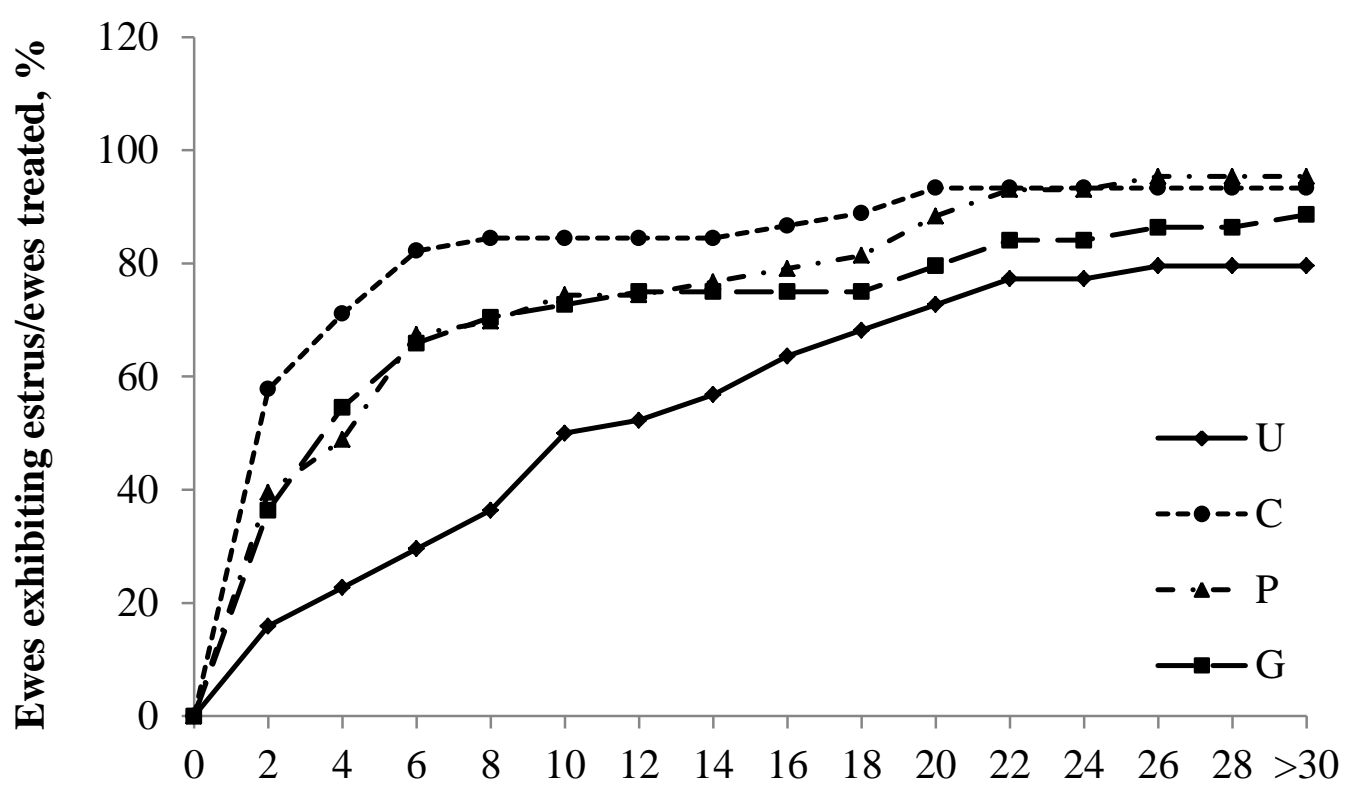

Days after ram introduction

Figure 2.2. Cumulative percentages of ewes that exhibited estrus per total ewes treated during the transition period in the various treatment protocols: $U=$ untreated; $C=C I D R$ inserted on $\mathrm{d}$ 5 and removed on $\mathrm{d} 0 ; \mathrm{P}=5 \mathrm{~d}$ CIDR and $\mathrm{PG}$ given at removal; $\mathrm{G}=\mathrm{GnRH}$ given on $\mathrm{d}-5,5 \mathrm{~d}$ $\mathrm{CIDR}$ and $\mathrm{PG}$ given at removal.

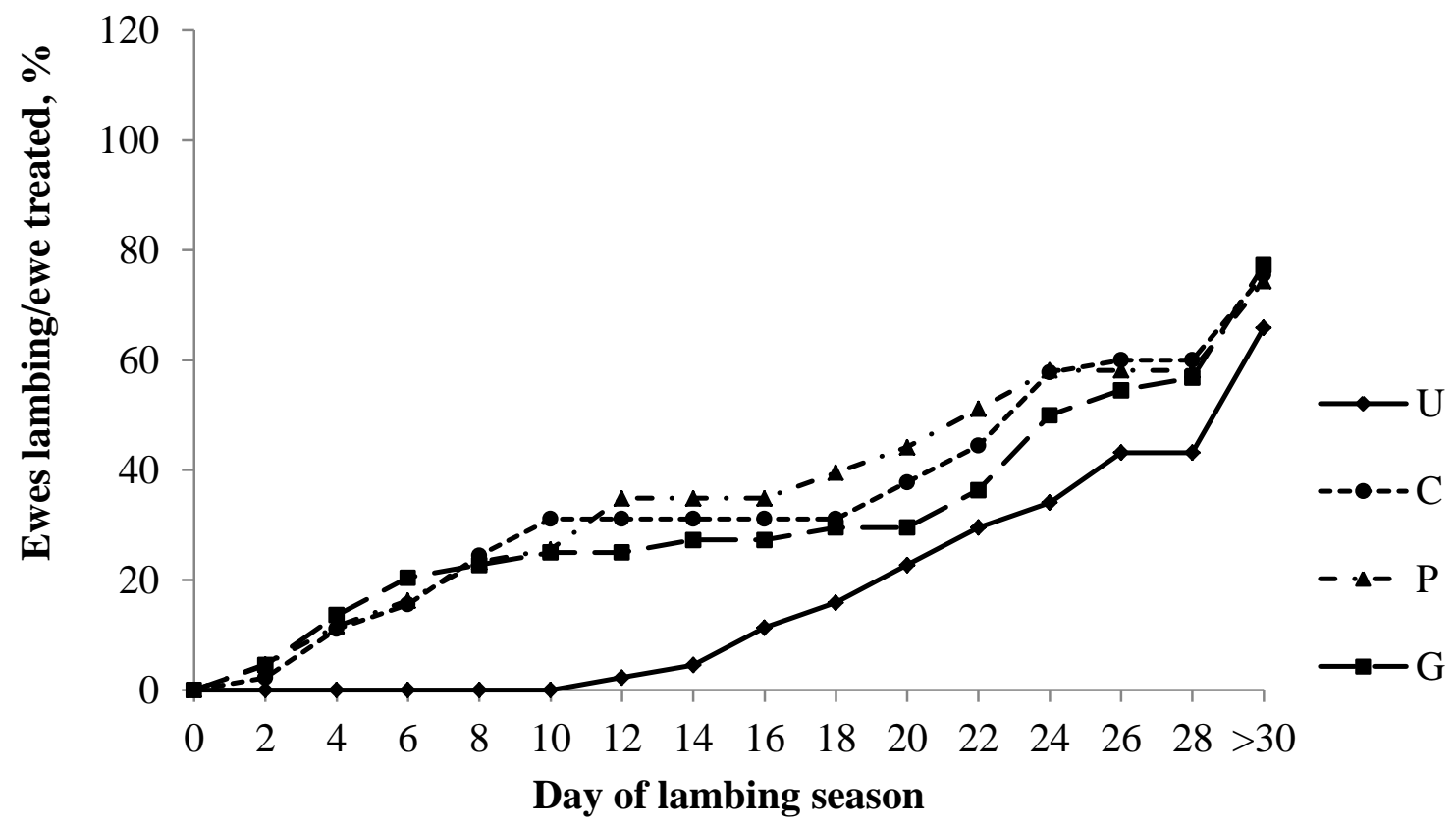

Figure 2.3. Cumulative percentages of ewes that lambed per ewes treated who were bred during the transition period to the various treatment protocols: $\mathrm{U}=$ untreated; $\mathrm{C}=\mathrm{CIDR}$ inserted on $\mathrm{d}$ 5 and removed on $\mathrm{d} 0 ; \mathrm{P}=5 \mathrm{~d}$ CIDR and $\mathrm{PG}$ given at removal; $\mathrm{G}=\mathrm{GnRH}$ given on $\mathrm{d}-5,5 \mathrm{~d}$ CIDR and $\mathrm{PG}$ given at removal. 
Table 2.1. Reproductive performance of ewes after $5 \mathrm{~d}$ controlled internal drug releasing (CIDR) synchronization protocols administered during the transition period

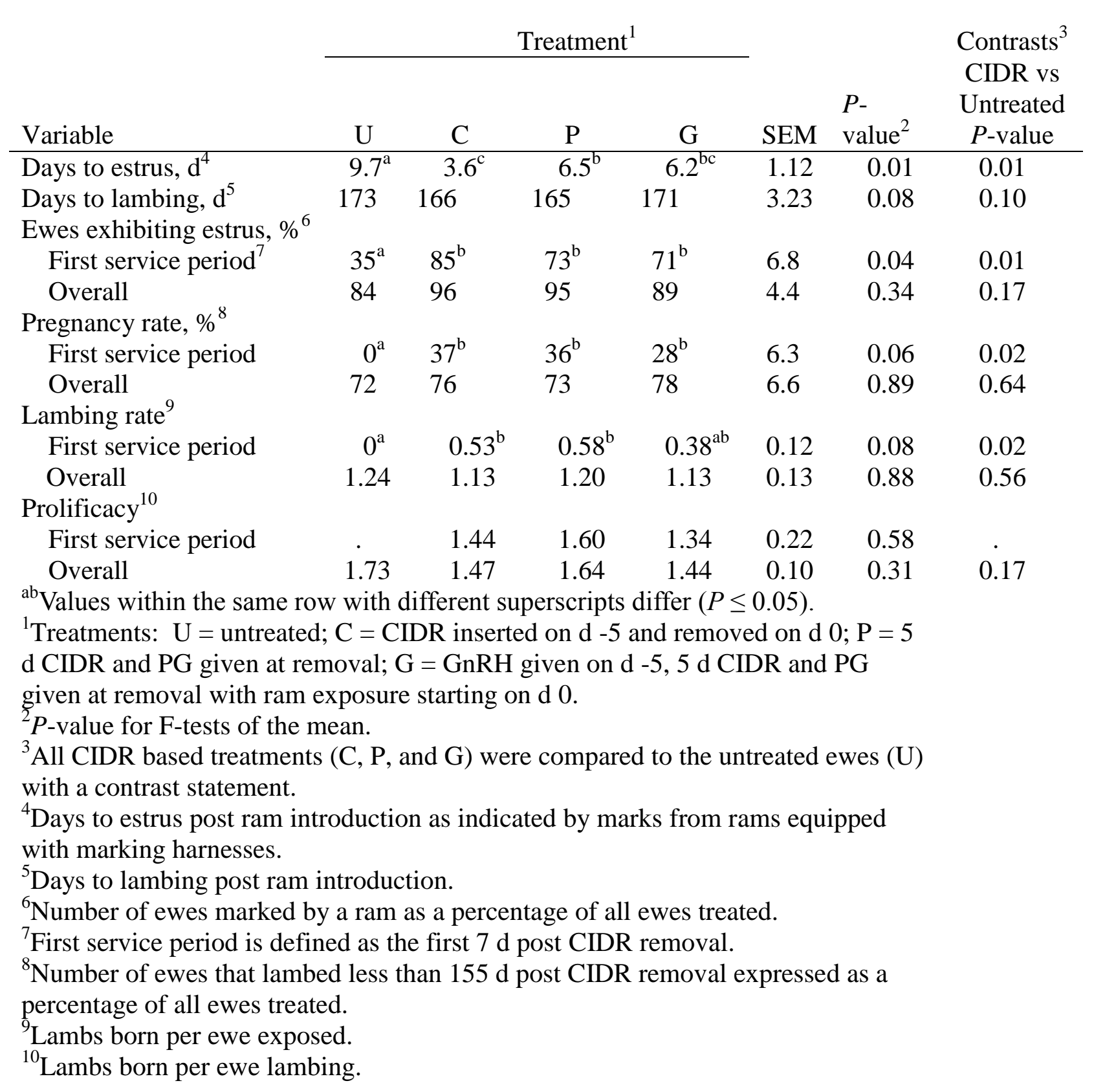

\section{Discussion}

Through the use of exogenous P4 the lifespan of the corpus luteum can be manipulated and aid in regulating estrus and ovulation (Hansel and Convey, 1983). In the current study, prior to treatment initiation, most ewes (63\%) were not fully cyclic as indicated by low P4 
concentrations as indicated by a P4 serum concentration sample less than $1 \mathrm{ng} / \mathrm{mL}$ on either day 12 or -5 . The CIDR provided exogenous $\mathrm{P} 4$ as evident by elevated $\mathrm{P} 4$ concentrations on $\mathrm{d} 0$ in all CIDR treatment groups (Figure 2.1). Consequently, serum P4 concentrations had decreased from $2.52,3.08$, and $2.81 \mathrm{ng} / \mathrm{mL}$ on $\mathrm{d} 0$ to $0.43,0.92$, and $0.89 \mathrm{ng} / \mathrm{mL}$ after CIDR removal (d 1) for C, P, and G; respectively. In contrast, untreated ewes had almost no change in P4 concentrations ( $1.15 \mathrm{ng} / \mathrm{mL}$ on $\mathrm{d} 0$ to $1.14 \mathrm{ng} / \mathrm{mL}$ on $\mathrm{d} 1)$. These values support previous findings by Ainsworth and Downey (1986) who reported a gradual decline in plasma P4 concentrations from $5.5 \mathrm{ng} / \mathrm{mL}$ to $1.7 \mathrm{ng} / \mathrm{mL}$ following CIDR removal.

Overall, the CIDR treated ewes had lower concentrations of P4 for 6 days after CIDR removal compared with $\mathrm{U}$. This decrease in concentrations of $\mathrm{P} 4$ indicates that the ewes were either in anestrous, proestrus or estrus.

Bartlewski et al. (1999) reported concentrations of P4 begin to increase between 3 and 7 $\mathrm{d}$ after estrus and then reach peak concentrations at approximately $\mathrm{d} 12$. In the current study, all ewes treated with a CIDR follow this fluctuation in concentrations of P4 with concentrations rising around $\mathrm{d} 8$ and plateauing at approximately $\mathrm{d} 10$ to 12 . This peak in concentrations of $\mathrm{P} 4$ is evident in the current study for all treatments receiving a CIDR had greater concentrations of $\mathrm{P} 4$ on $\mathrm{d} 12$ compared with $\mathrm{U}$. It appears $\mathrm{U}$ ewes were receptive to the ram effect which is evident by delayed increase in P4 concentration compared to CIDR treated ewes. This lag period was similar to Schinckel (1954), who reported a lag period of 14 days post ram introduction.

Days to estrus were reduced by 6 days in $\mathrm{C}$ treated ewes and by 3 days for all the remaining ewes receiving a $5 \mathrm{~d}$ CIDR treatment. This is consistent with Wheaton et al. (1992) who reported a reduced interval to estrus in ewes treated with a CIDR compared with untreated ewes. In the current study, no differences were detected in overall days to lambing in untreated 
ewes (173 d) and ewes treated with a 5 d CIDR (167 d). This however, is in agreement with Titi et al. (2010) who reported no differences in days to lambing between those ewes treated with an exogenous P4 source for 5 days (average $166 \mathrm{~d}$ ) and control ewes (174 d). Of all ewes treated with a $5 \mathrm{~d}$ CIDR insert included in the treatment protocol that exhibited estrus, a majority (80\%) came into estrus within $7 \mathrm{~d}$ after ram introduction; whereas, only $43 \%$ (Figure 2.2) of untreated ewes came into estrus during this period. This data is consistent to the findings reported by Knights et al. (2001a and 2001b) in which P4 treated ewes had a greater proportion of ewes marked by rams within the first $5 \mathrm{~d}$ after ram introduction compared with control ewes. Although no differences were observed in the percentage of ewes exhibiting estrus overall, the findings in the current study are in close agreement with a study by Wheaton et al. (1992) in which $95 \%$ of untreated ewes and $100 \%$ of ewes receiving a CIDR for $12 \mathrm{~d}$ exhibited estrus.

In this study, all ewes treated with a $5 \mathrm{~d}$ CIDR showed an improvement in pregnancy and lambing rate during the first 7 days of ram introduction; however, overall pregnancy rates and lambing rates were not improved by CIDRs when compared with untreated ewes. Moreover, we failed to detect any differences in overall pregnancy or lambing among treatment protocols. This study is in agreement with two studies conducted by Knights et al. (2001a and 2001b) who reported similar results $(0 \%)$ for pregnancy rate and lambing rate to the first service period in control ewes compared with ewes receiving a $5 \mathrm{~d}$ CIDR treatment. Of the untreated ewes that lambed, $0 \%$ lambed within the first $7 \mathrm{~d}$ of the lambing season (Figure 2.3). Of those ewes treated with a CIDR, only $27 \%$ lambed within the first $7 \mathrm{~d}$ of the breeding season and $76 \%$ lambed overall (Figure 2.3). These findings are not in agreement with Carlson et al. (1989) and Knights et al. (2001a) who reported $74 \%$ and 60 to $70 \%$, respectively, that were treated with P4, lambed within the first service period. Titi et al. (2010) reported an increase in prolificacy in 
ewes treated with GnRH and PG coupled with an exogenous P4 source which is in disagreement with the current study, in which no differences were detected in prolificacy to both the first service period and overall.

\section{Implications}

In the current study, any protocol containing a $5 \mathrm{~d}$ CIDR insert decreased overall days to detected estrus; however, days to detected estrus were reduced the most when a $5 \mathrm{~d}$ CIDR was used alone. Surprisingly though, the use of a $5 \mathrm{~d}$ CIDR did not reduce overall days to lambing. Additionally, a greater proportion of ewes treated with a $5 \mathrm{~d}$ CIDR exhibited estrus to the first service period; however, there was no difference in the percentage of ewes exhibiting estrus overall. A greater percentage of ewes treated with a $5 \mathrm{~d}$ CIDR protocol became pregnant and lambed to the first service period. In regards to overall lambing rate and prolificacy, untreated ewes performed just as well reproductively as those ewes treated with a $5 \mathrm{~d}$ CIDR. Therefore, our research found the current management practices recommended to induce ewes into estrus (flushing and ram exposure) were equally effective as utilization of the $5 \mathrm{~d}$ CIDR to induce ewes into estrus during the transition period. More research still needs to be conducted to identify effective applications of the recently approved $5 \mathrm{~d}$ CIDR for its use on commercial sheep operations to enhance overall ewe reproductive performance. 


\title{
CHAPTER 3. OUT-OF-SEASON REPRODUCTIVE PERFORMANCE OF EWES SYNCHRONIZED TO ESTRUS WITH VARIOUS FIVE-DAY CIDR PROTOCOLS
}

\begin{abstract}
The objective of this experiment was to evaluate the reproductive performance of ewes after synchronization to estrus with progesterone (P4) impregnated controlled internal drug releasing (CIDR) inserts in combination with gonadotropin-releasing hormone $(\mathbf{G n R H})$ and prostaglandin (PG). Dorset and Katahdin ewes ( $\mathrm{n}=61$ and 17, respectively) were assigned randomly during the anestrous period (April) to 1 of 4 treatments: 1) Untreated $(\mathbf{U} ; n=16) ; 2) 5$ d CIDR (0.3 g P4) insert (C; $\mathrm{n}=21) ; 3) 5 \mathrm{~d}$ CIDR and PG (dinoprost, $10 \mathrm{mg}$ i.m.) at CIDR removal (P; n = 20); and 4) GnRH (gonadorelin, $0.02 \mathrm{mg}$ i.m.) at CIDR insertion and PG at CIDR removal $(\mathbf{G} ; \mathrm{n}=21)$. Rams equipped with marking harnesses were introduced at CIDR removal ( $\mathrm{d}$ 0) and ewes were observed at $0800 \mathrm{~h}$ and $1700 \mathrm{~h}$ daily for breeding marks starting on d 0 . Blood samples were collected via jugular venipuncture on $\mathrm{d}-12,-5,0,1,2,3,4,5,8,11$, 14,17 , and 20 relative to CIDR removal and analyzed for serum concentrations of P4 via radioimmunoassay (RIA). Data collected included: days to estrus, days to lambing, percentage of ewes exhibiting estrus, pregnancy rate, lambing rate, and prolificacy. A treatment $\times$ time interaction $(P \leq 0.05)$ was present for concentrations of $\mathrm{P} 4$. Concentrations of $\mathrm{P} 4$ were decreased $(P \leq 0.04)$ in $\mathrm{G}$ compared with $\mathrm{U}$ on $\mathrm{d} 2$. On d $14, \mathrm{C}$ and $\mathrm{P}$ had greater $(P \leq 0.03)$ concentrations of $\mathrm{P} 4$ and $\mathrm{G}$ tended $(P=0.06)$ to have greater $\mathrm{P} 4$ concentrations compared with U. In contrast, concentrations of P4 on d 20 were greater $(P \leq 0.03)$ in U compared with C. Days to estrus after CIDR removal, as indicated by breeding marks, were greater $(P \leq 0.02)$ in $\mathrm{U}(6.5 \pm$ $1.05 \mathrm{~d})$ and $\mathrm{P}(5.9 \pm 0.88 \mathrm{~d})$ compared with $\mathrm{G}(3.0 \pm 0.88)$. Pregnancy rate within $7 \mathrm{~d}$ post CIDR removal were similar $(P=0.57)$ in the current study for $\mathrm{U}, \mathrm{C}, \mathrm{P}$, and $\mathrm{G}(30 \%, 5$ of $16 ; 30 \%, 7$ of
\end{abstract}


$21 ; 35 \%, 7$ of 20 ; and $51 \%, 11$ of 21 ; respectively). Similarly, no differences $(P \geq 0.32)$ were detected for pregnancy rate overall and lambing rate and prolificacy to the first service period and overall. It appeared the $5 \mathrm{~d}$ CIDR alone or coupled with $\mathrm{GnRH}$ and PG improved estrus synchronization; however, reproductive performance was not improved by any of the $5 \mathrm{~d}$ CIDR protocols. These results warrant further research to determine the efficacy of industry-wide application of the $5 \mathrm{~d}$ CIDR in anestrous ewes.

\section{Introduction}

Controlled internal drug releasing (CIDR) inserts were approved for use in sheep by the U.S. Food and Drug Administration (FDA) in 2009. Prior to approval, common industry practice was to insert a CIDR for 12 to $14 \mathrm{~d}$ with or without an injection of gonadotropin at removal (Rhodes and Nathanielsz, 1988; Carlson et. al, 1989; Wildeus, 2000; Abecia and Gonzalez-Bulnes, 2012). The current label recommendation is to insert one CIDR per ewe for 5 $d$ with the intention of inducing estrus in ewes during the anestrous season (FDA, 2009). Use of the CIDR as a synchronization tool could benefit sheep producers by condensing the lambing season and reducing labor, feed, and facility costs. Producers strategically selling lamb during ethnic holidays and 'out-of-season' can take advantage of increased lamb prices at these times. In addition, uniform lamb crops are easier to manage and market (Carlson et al., 1989).

In two studies by Knights et al. (2001a; 2001b), a 5 d CIDR treatment was found to stimulate an effective estrus response in seasonally anestrous ewes compared with untreated ewes. Addition of a prostaglandin (PG) injection at CIDR removal elicited a greater percentage of ewes observed in estrus and a greater lambing rate to the first service period compared with ewes treated with PG alone (Dixon et al., 2006). Moreover, in a recent study, Titi et al. (2010) reported improvements in estrous synchronization and prolificacy with the inclusion of an 
injection of GnRH prior to insertion and PG at removal of intravaginal P4 sponges for $5 \mathrm{~d}$ during the breeding season. Limited research has been conducted utilizing the $5 \mathrm{~d}$ CIDR in combination with GnRH and PG in seasonally anestrous ewes. Therefore, we hypothesized ewes receiving a CIDR coupled with GnRH and PG treatment would display a more synchronized estrus when compared with untreated ewes. The objective of this study was to determine the efficacy and reproductive performance of ewes during the anestrous season after synchronization to estrus with P4 impregnated CIDR inserts in conjunction with GnRH and PG.

\section{Materials and Methods}

All procedures involving animals used in this research were approved by the North Dakota State University Institutional Animal Care and Use Committee, IACUC \#A11007.

\section{Experimental Design}

In April 2011, during the anestrous period, multiparous and nulliparous Dorset and Katahdin ( $\mathrm{n}=61$ and $\mathrm{n}=17$, respectively) ewes from the North Dakota State University Sheep Unit in Fargo, ND, were randomly assigned to 1 of 4 treatments: 1) Untreated $(\mathbf{U}, \mathrm{n}=16) ; 2) 5 \mathrm{~d}$ CIDR insert (EAZI-BREED CIDR Sheep Insert, 0.3 g P4, Pfizer Animal Health, New York, NY), inserted on d $-5(\mathbf{C}, \mathrm{n}=21)$; 3) $5 \mathrm{~d}$ CIDR and PG (Lutalyse, $10 \mathrm{mg} / \mathrm{mL}$ dinoprost tromethamine i.m., Pfizer Animal Health, New York, NY) at CIDR removal $(\mathbf{P}, \mathrm{n}=20)$; and 4) GnRH (Factrel, 0.02 mg/mL gonadorelin hydrochloride i.m., Pfizer Animal Health, New York, NY) given at $5 \mathrm{~d}$ CIDR insertion and PG at CIDR removal $(\mathbf{G}, \mathrm{n}=21)$. Prior to treatment application, ewes were managed as a common group in a dry lot and isolated from all males. Once treatments were initiated, ewes had ad-libitum access to alfalfa hay and had continuous access to fresh water. Four intact rams were equipped with marking harnesses and introduced to ewes immediately post CIDR removal with a ewe to ram ratio not exceeding 25:1. Ewes were 
observed for breeding marks (detected estrus) twice daily at $0800 \mathrm{~h}$ and $1700 \mathrm{~h}$ and ewes remained with rams for $42 \mathrm{~d}$.

\section{Blood Collection and Analysis}

Blood samples were collected via jugular venipuncture into $10 \mathrm{~mL}$ serum tubes (BD Vacutainer Serum, Becton, Dickinson and Company, Franklin Lakes, NJ) on d -12, -5, 0, 1, 2, 3, $4,5,8,11,14,17$, and 20 relative to CIDR removal (d 0). Samples were immediately placed on ice for $2 \mathrm{~h}$ prior to centrifugation, centrifuged at $4^{\circ} \mathrm{C}$ for $30 \mathrm{~min}$ at $1,500 \times \mathrm{g}$ and serum was transferred into plastic $2.0 \mathrm{~mL}$ microcentrifuge tubes and frozen at $-20{ }^{\circ} \mathrm{C}$ until assayed. Serum samples were assayed for circulating P4 using a solid-phase, no-extraction RIA (Coat-a-Count Progesterone, Diagnostic Products Corporation, Los Angeles, CA; Stevenson et al., 2011). The assay kit was validated for ovine serum using an assay volume of $100 \mu$ l (Hamra et al., 1986;

Schneider and Hallford, 1996). Assay tubes for the standard curve contained 0.1, 0.25, 0.5, 1.0, 2.0, 5.0, 10.0, and $20 \mathrm{ng} / \mathrm{ul}$. Assay sensitivity for a $100-\mu 1$ sample was $0.1 \mathrm{ng} / \mathrm{mL}$. Ewes were determined to be cycling if serum P4 concentrations were greater than $1 \mathrm{ng} / \mathrm{mL}$ in either or both the $\mathrm{d}-12$ or -5 samples. All samples for a single ewe were analyzed within the same assay and treatments were run in a random order. The intra- and inter-assay CVs were 2.28 and 2.21\%, respectively.

\section{Reproductive Performance}

Data collected included: days to estrus, days to lambing, percent ewes exhibiting estrus, pregnancy rate, lambing rate, and prolificacy. The number of ewes marked by a ram as a percentage of all ewes on study was represented by the percent of ewes exhibiting estrus. Pregnancy rate was defined as the number of ewes lambing as a percentage of ewes in all treatments and the number of lambs born per ewe exposed to rams is represented by lambing 
rate. Lastly, prolificacy was the number of lambs born per ewe lambing. These components were classified as either to the first service period which was $7 \mathrm{~d}$ post CIDR removal or overall beginning from d 0 until rams were removed at $\mathrm{d} 42$.

\section{Statistical Analysis}

Repeated measures of the MIXED procedure of SAS (SAS Inst., Inc., Cary, NC) were used to analyze serum concentrations of P4. The model included the main effects of treatment, time, cycling status, and treatment $\times$ time interaction. Days to detected estrus and days to lambing were examined using the MIXED procedures of SAS. Effects of the model included treatment, breed, age, cycling status, and all possible interactions. Percent ewes exhibiting estrus, lambing rate and prolificacy were analyzed using the GLIMMIX procedures of SAS. The model included the main effects of treatment, breed, age, cycling status, and their respective interactions. Contrast statements were run to compare all CIDR treatment groups against untreated ewes for days to estrus, days to lambing, percent ewes exhibiting estrus, pregnancy rate, lambing rate and prolificacy to both the first service period and overall. Data are presented as least square means and treatment differences were considered significant at $P \leq 0.05$. Interactions with a $P$-value $>0.20$ were removed from the model.

\section{Results}

\section{Serum Concentrations of Progesterone}

A treatment $\times$ time interaction $(P \leq 0.05$, Figure 3.1$)$ for concentrations of $\mathrm{P} 4$ was detected. Concentrations of P4 were lower $(P \leq 0.04)$ in $\mathrm{G}$ compared with $\mathrm{U}$ on $\mathrm{d} 2$. No differences were detected $(P=0.64)$ among treatments in $\mathrm{P} 4$ concentrations. After $\mathrm{d} 14$, serum

P4 concentrations of ewes in the $\mathrm{U}$ treatment increased to levels similar to all other treatments $(P$ $>0.10$; Figure 3.1). On d 14, $\mathrm{C}$ and $\mathrm{P}$ had greater $(P \leq 0.03$; Figure 3.1$)$ concentrations of $\mathrm{P} 4$ 
and $\mathrm{G}$ tended $(P=0.06)$ to have greater $\mathrm{P} 4$ concentrations compared with $\mathrm{U}$. In contrast, concentrations of $\mathrm{P} 4$ on d 20 were greater $(P \leq 0.03)$ in $\mathrm{U}$ compared with $\mathrm{C}$.

\section{Reproductive Performance Data}

All ewes treated with a CIDR exhibited estrus in less days post ram introduction $(P=$ 0.04; Table 3.1) than the untreated ewes. Among treatments, $\mathrm{G}$ and $\mathrm{C}$ treated ewes exhibited estrus in less days $(P<0.02)$ than $\mathrm{U}$ treated ewes; whereas, $\mathrm{P}$ treated ewes did not differ $(P=$ 0.07) from $U$ treated ewes. Furthermore, $G$ treated ewes exhibited estrus in less days $(P=0.02)$ than $\mathrm{P}$ treated ewes. No differences $(P=0.55$; Table 3.1$)$ were detected among ewes for days to lambing. No differences were detected ( $P \geq 0.32$; Table 3.1) among treatments for percentage of ewes exhibiting estrus to the first service period and overall. Pregnancy rate to the first service period, $7 \mathrm{~d}$ post CIDR removal, were similar $(P=0.57$; Table 3.1$)$ in the current study for $\mathrm{U}, \mathrm{C}$, $\mathrm{P}$, and $\mathrm{G}(30 \%, 5$ of $16 ; 30 \%, 7$ of $21 ; 35 \%, 7$ of 20 ; and $51 \%, 11$ of 21 , respectively). No differences $(P \geq 0.36$; Table 3.1) were observed among treatments for overall pregnancy rate and lambing rate. Similarly, no differences $(P>0.36)$ were detected for prolificacy to the first service period and overall. 


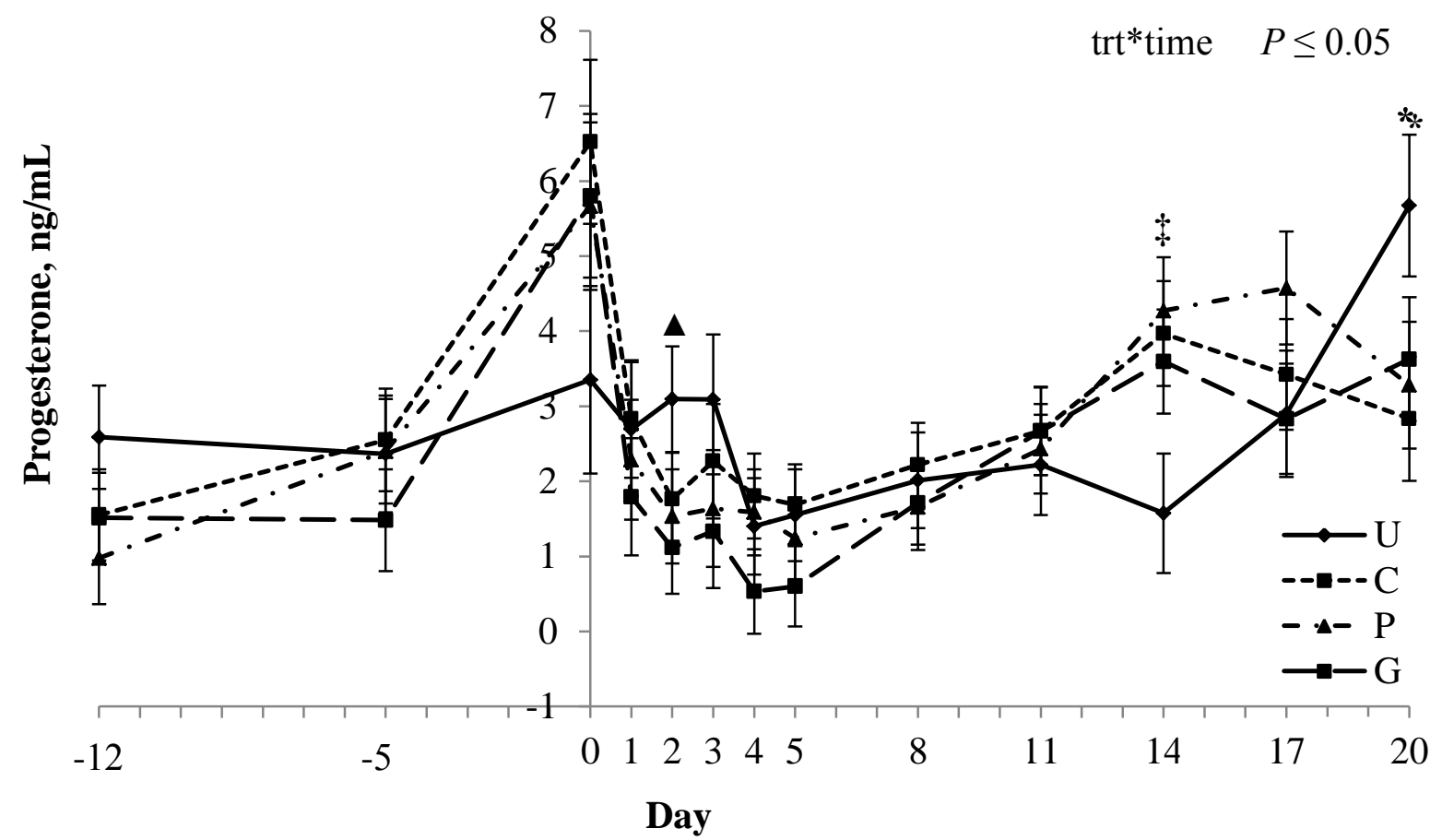

Figure 3.1. Serum progesterone (P4) profiles before and after $5 \mathrm{~d}$ controlled internal drug releasing (CIDR) synchronization treatment protocols administered during the anestrous season. Treatments: $\mathrm{U}=$ untreated; $\mathrm{C}=\mathrm{CIDR}$ inserted on $\mathrm{d}-5$ and removed on $\mathrm{d} 0 ; \mathrm{P}=5 \mathrm{~d}$ CIDR and $\mathrm{PG}$ given at removal; $\mathrm{G}=\mathrm{GnRH}$ given on $\mathrm{d}-5,5 \mathrm{~d} \mathrm{CIDR}$ and $\mathrm{PG}$ given at removal. A treatment $\times$ time interaction was detected $(P \leq 0.05) . \quad \Delta=\mathrm{U}$ had greater concentrations of $\mathrm{P} 4$ compared with $\mathrm{G}$ on $\mathrm{d} 2(P \leq 0.05)$. $\$=\mathrm{C}$ and $\mathrm{P}$ had greater $\mathrm{P} 4$ concentrations compared with $\mathrm{U}$ on $\mathrm{d} 14$ $(P \leq 0.05){ }^{*}=\mathrm{C}$ had lower concentrations of $\mathrm{P} 4$ compared with $\mathrm{U}$ on $\mathrm{d} 20(P \leq 0.05)$. 


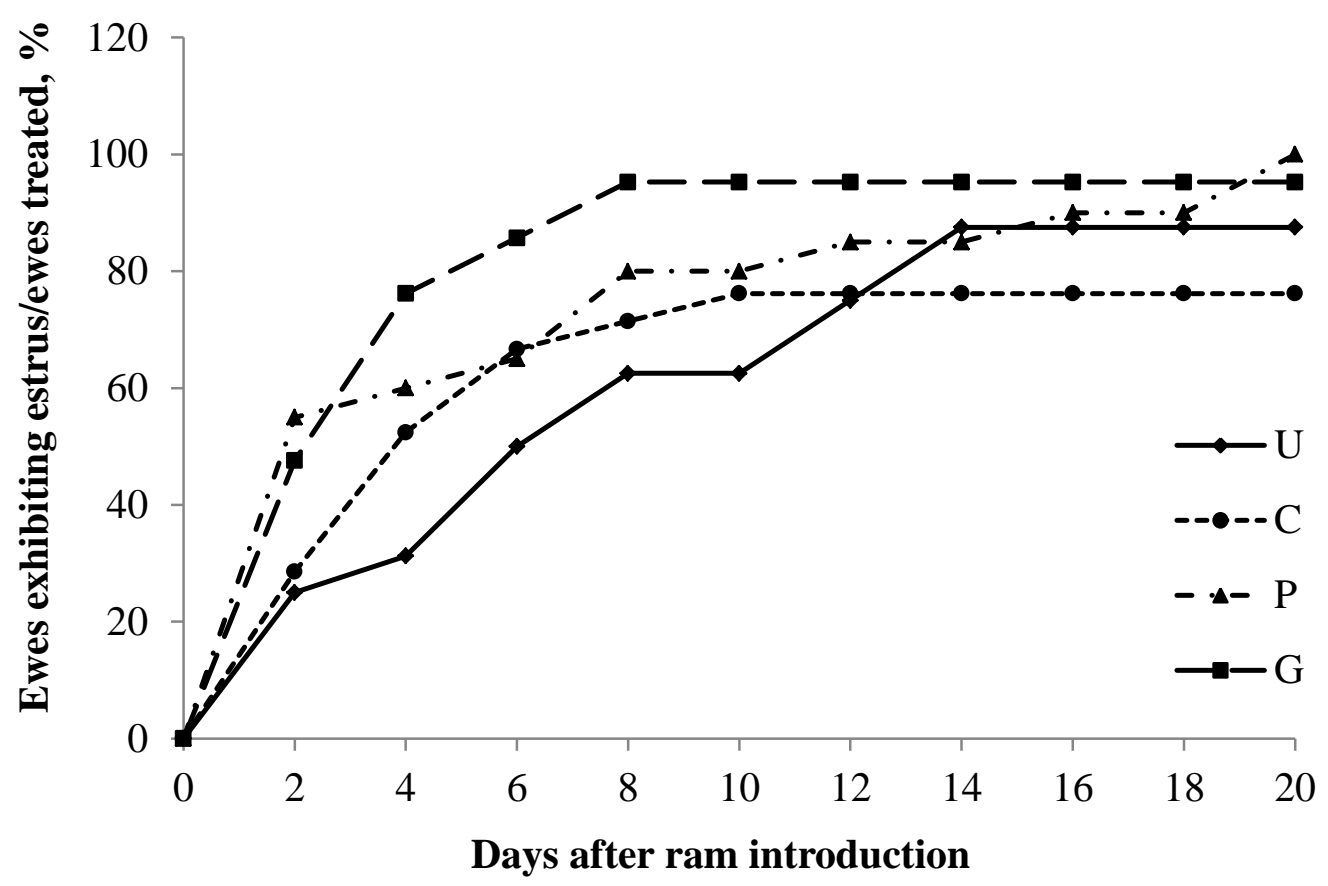

Figure 3.2. Cumulative percentages of ewes that exhibited estrus per total ewes treated during the anestrous season in the various treatment protocols: $\mathrm{U}=$ untreated; $\mathrm{C}=\mathrm{CIDR}$ inserted on $\mathrm{d}$ 5 and removed on $\mathrm{d} 0 ; \mathrm{P}=5 \mathrm{~d}$ CIDR and $\mathrm{PG}$ given at removal; $\mathrm{G}=\mathrm{GnRH}$ given on $\mathrm{d}-5,5 \mathrm{~d}$ CIDR and $\mathrm{PG}$ given at removal.

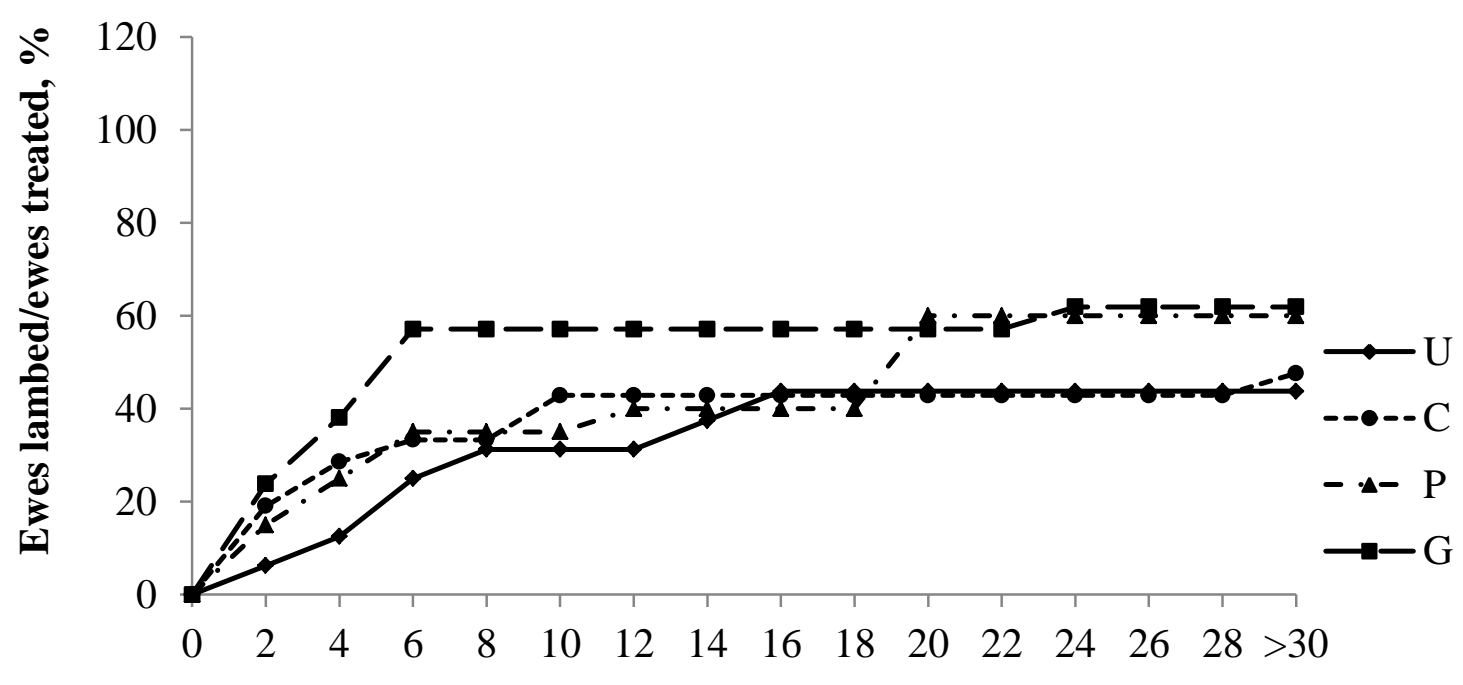

Day of lambing season

Figure 3.3. Cumulative percentages of ewes that lambed per ewes treated who were bred during the anestrous season to the various treatment protocols: $\mathrm{U}=$ untreated; $\mathrm{C}=\mathrm{CIDR}$ inserted on $\mathrm{d}$ 5 and removed on $\mathrm{d} 0 ; \mathrm{P}=5 \mathrm{~d}$ CIDR and $\mathrm{PG}$ given at removal; $\mathrm{G}=\mathrm{GnRH}$ given on $\mathrm{d}-5,5 \mathrm{~d}$ CIDR and PG given at removal. 
Table 3.1. Reproductive performance of ewes after $5 \mathrm{~d}$ controlled internal drug releasing (CIDR) synchronization protocols administered during the anestrous season

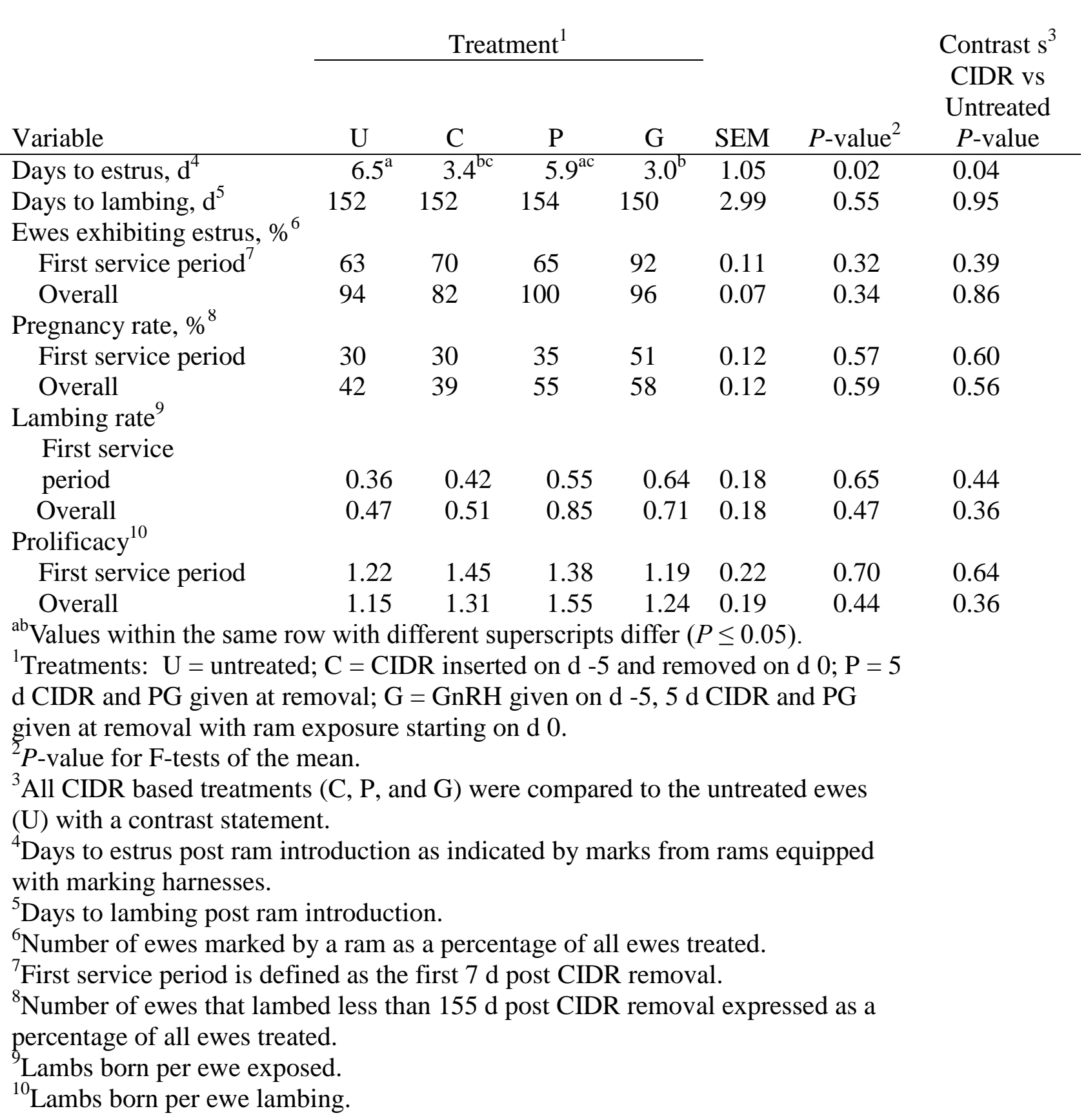

\section{Discussion}

In the present study, as expected, all treatments receiving a $5 \mathrm{~d}$ CIDR insert showed numerically elevated concentrations of P4 at CIDR removal compared with $\mathrm{U}$ ewes. The 
reduction in concentrations of $\mathrm{P} 4$ from $\mathrm{d} 0$ to $\mathrm{d} 2$, suggests decreased luteal activity which may lead to a more uniform synchronization to estrus. It appears, the administration of GnRH $5 \mathrm{~d}$ prior to CIDR insertion and PG at CIDR removal potentially induced ovulation and/or caused luteinization of the dominant follicle which is evident by the decreased concentrations of P4 in G compared with $\mathrm{U}$ on $\mathrm{d} 2$, thus indicating more ewes were potentially in estrus within $48 \mathrm{hr}$ post CIDR removal. Prior to treatment initiation, a majority (62\%) of ewes were classified as cycling as indicated by a $\mathrm{P} 4$ serum concentration sample greater than $1 \mathrm{ng} / \mathrm{mL}$ on either or both $\mathrm{d}-12$ or -5. In contrast, only 37\% of ewes in Experiment 1 were cycling prior to CIDR insertion. Cyclicity during the anestrous season is not uncommon for the Dorset and Katahdin breed; however, since the overall pregnancy rate (42\%) for $\mathrm{U}$ ewes was numerically lower than the cycling rate $(62 \%)$, perhaps the ewes were not fully cyclic. It has been documented that a semicyclic pattern in ovarian activity is evident during early and late anestrous ewes (Cole and Miller, 1935). Although no differences were detected among treatments in concentrations of $\mathrm{P} 4$, the $\mathrm{U}$ treated ewes, had a mean P4 concentration of $3.35 \mathrm{ng} / \mathrm{mL}$ on d 0 followed by decreased P4 concentrations on $\mathrm{d} 4$ to $1.40 \mathrm{ng} / \mathrm{mL}$ (Figure 3.1). The decrease in $\mathrm{P} 4$ concentrations may have been a result of a short cycle, where the corpus luteum $(\mathbf{C L})$ develops a shorter than normal lifespan or the follicular phase induced by the first exposure to the ram was too short (Martin et al., 1986). Perhaps ram introduction stimulated cyclicity in the U group and they developed a functional CL to produce similar quantities of P4 compared with the other treatments. These results are consistent with Martin et al. (1986), who reported that after $6 \mathrm{~d}$ of the short cycle, a second ovulation is induced followed by a fertile cycle of normal length. This apparent effect of ram introduction provides justification that a majority of the ewes were either non-cyclic or 
semi-cyclic. After d 14, serum P4 concentrations of ewes in the U treatment increased to levels similar to all other treatments.

All ewes treated with a $5 \mathrm{~d}$ CIDR incorporated into the designated treatment protocols came into estrus approximately $3 \mathrm{~d}$ earlier than those ewes not treated with a CIDR (Table 3.1). The $\mathrm{C}$ and $\mathrm{G}$ treated ewes came into estrus more quickly post ram introduction than the $\mathrm{P}$ treated ewes and the untreated ewes. This data suggests $\mathrm{C}$ and $\mathrm{G}$ treated ewes displayed a tighter synchrony to estrus. Wheaton et al. (1992) also observed ewes treated with a CIDR having a reduced interval to estrus compared with $\mathrm{U}$ ewes. In the current study, no differences were detected in overall days to lambing among treatment groups as well as all ewes receiving a $5 \mathrm{~d}$ CIDR compared with untreated ewes. This is in disagreement with Knights et al. (2001a), who reported $42 \%$ of anestrous ewes treated with a $5 \mathrm{~d}$ CIDR lambed (approximately 12 to $13 \mathrm{~d}$ ) earlier than untreated ewes (165 d; Table 3.1). Similar to Knights, et al. (2001a), Wheaton, et al. (1993), reported ewes in anestrous who were treated with a CIDR for $12 \mathrm{~d}$ took fewer days (157 \pm 2 d) to lamb post ram introduction compared with control ewes (170 \pm 2 d). The majority of ewes treated with a CIDR that exhibited estrus came into estrus within $7 \mathrm{~d}$ after ram introduction (86\%) compared with U ewes (64\%; Figure 3.2). Even though no differences were detected among treatments for percentage of ewes exhibiting estrus to the first service and overall, in a study by Wheaton et al. (1992), the percentage of untreated ewes (95\%) exhibiting estrus overall and those receiving a CIDR insert for $12 \mathrm{~d}(100 \%)$ were similar to the percentage of untreated ewes exhibiting estrus overall (94\%) in the current study. In two separate reports, Knights et al. (2001a, 2001b) reported a greater proportion of P4 treated ewes were marked by rams compared with control ewes. 
Pregnancy rate within $7 \mathrm{~d}$ post CIDR removal were similar in the current study for $\mathrm{U}, \mathrm{C}$, $\mathrm{P}$, and $\mathrm{G}(30 \%, 5$ of $16 ; 30 \%, 7$ of $21 ; 35 \%, 7$ of 20 ; and $51 \%, 11$ of 21 ; respectively). In contrast, Knights et al. (2001a, 2001b) documented greater pregnancy rates to the first service period and an increase in lambing rate (Knights, 2000) in P4 treated ewes compared with control ewes. Although no differences were observed among treatments for lambing rate and prolificacy in the current study, the majority of ewes treated with a CIDR that lambed, did so during the first $7 \mathrm{~d}$ (74\%; Figure 3.3). A similar pattern of lambing was reported by Carlson et al. (1989); in their study, 74\% of ewes treated with P4 lambed within 6 d. Knights et al. (2001) also reported that 60 to $70 \%$ of ewes treated with P4 that lambed, did so during the first $8 \mathrm{~d}$. In the current study, only $31 \%$ (Figure 3.3) of untreated ewes lambed within the first $7 \mathrm{~d}$ of the lambing season compared with $42 \%$ of all ewes treated with a $5 \mathrm{~d}$ CIDR. In contrast to the current study, Titi et al. (2010) reported an increase in fecundity in ewes treated with exogenous P4 when coupled with the use of GnRH and PG. Although no differences were detected among reproductive performance data, this study suggests that $\mathrm{C}$ and $\mathrm{G}$ treatments were more effective at concentrating estrus shortly after CIDR removal compared with $\mathrm{U}$ and $\mathrm{P}$ treatments.

\section{Implications}

In the current study, the recently approved sheep CIDR which is recommended to be used for 5 days during the anestrous period, when used alone was not effective in generating synchronization results desired by most commercial sheep producers. However, when the $5 \mathrm{~d}$ CIDR was coupled with GnRH and PG, estrus synchronization was improved in ewes by decreasing the overall days to estrus when compared with untreated ewes during the anestrous season. Unfortunately though, the $5 \mathrm{~d}$ CIDR, regardless of what protocol it was incorporated into did not influence reproductive performance. The efficacy of CIDR protocols to synchronize 
estrus and improve fertility during the anestrous period was not clearly demonstrated in this study and more research is needed prior to recommendation of the $5 \mathrm{~d}$ CIDR in the commercial sheep industry. 


\section{CHAPTER 4. SUMMARY AND CONCLUSIONS}

Producers rely greatly on the reproductive success of their flock in terms of the frequency of lambings that occur each year as well increasing the number of lambs born per ewe lambing in order to remain competitive and to ensure their livelihood in the future. Sheep are known for their seasonality, in which they typically breed in the fall and lamb in the spring. For producers to get more than one lambing in per year, ewes need to breed during the anestrous season. Through the development of advanced reproductive tools and recent approval by the Food and Drug Administration (FDA) of controlled internal drug release (CIDR) inserts for the use in sheep in the United States (U.S.), out-of-season breeding is becoming more of a reality than ever before.

To our knowledge, these experiments are the first to look at serum concentrations of progesterone (P4) in ewes treated with various $5 \mathrm{~d}$ estrus synchronization protocols that utilize a CIDR infused with P4 alone or coupled with either prostaglandin (PG) and gonadotropinreleasing hormone (GnRH). This study showed the $5 \mathrm{~d}$ CIDR decreased overall days to estrus (3.6 d) the most for ewes bred during the transition season when compared with untreated (9.7 d) ewes. It was reported in a study by Glimp (1971) that Hampshire and Rambouillet ewes took on average $17.7 \pm 1.5 \mathrm{~d}$ and $12.6 \pm 1.5 \mathrm{~d}$ to come into estrus to the first service period which is close to the results of the similar study (9.7 d). During the anestrous season, ewes receiving GnRH prior to CIDR insertion and PG at removal had the least days to detected estrus (3.4 d) overall when compared with untreated ewes $(6.5 \mathrm{~d})$. By reducing the days in which sheep are bred, ideally the overall breeding and lambing seasons will be condensed, thereby enhancing the opportunity for producers to reduce labor costs associated with lambing, produce a more consistent lamb crop, and potentially engage in an accelerated lambing program. 
Not only are producers concerned with and strive for maximal number of lambs born per ewe lambing, but they also aim to reduce the number of days in the breeding season. In the current study, reproductive performance in regards to pregnancy rate, lambing rate, and prolificacy to both the first service period and overall were not affected by any of the treatment protocols that utilized a $5 \mathrm{~d}$ CIDR. Untreated ewes appeared to respond considerably well to the ram effect, although not statistically significant, for they displayed an increase in the percentage of ewes in estrus, pregnancy rate and lambing rate from the first service period to overall, especially during the transition season. Prolificacy in the untreated ewes was numerically greater than all treatments receiving a CIDR in Experiment 1, although this was not statistically significant. Reproductively, it appears the untreated ewes performed just as well as their contemporaries.

Collectively, our study would suggest that producers can expect to see comparable reproductive results in ewes treated with a $5 \mathrm{CIDR}$ alone or when coupled with various hormonal treatments when compared to those ewes not treated at all. However, through the use of CIDRs, producers can decrease overall days to detected estrus. Perhaps a more cost effect approach would be to use teaser rams to induce the ram effect on ewes. Therefore, producers would need to advance the turn-out of teasers by two weeks in order to stimulate the ewes into estrus and to exhibit a fertile estrus at the desired date of ram turn out. Much research still needs to be conducted utilizing the $5 \mathrm{~d}$ CIDR coupled with various hormonal treatments to truly determine the efficacy of the $5 \mathrm{~d}$ CIDR, along with establishing potential universal synchronization protocols that commercial sheep operations can follow and implement into their current breeding programs. 


\section{LITERATURE CITED}

Abecia, J. A., F. Forcada, and A. Gonzalez-Bulnes. 2011. Pharmaceutical control of reproduction in sheep and goats. Vet. Clin. N. Am-Food. A. 27:67-79.

Abecia, J. A., F. Forcada, and A. Gonzalez-Bulnes. 2012. Hormonal control of reproduction in small ruminants. Anim. Reprod. Sci. 130:173-179.

Ainsworth, L., and B. R. Downey. 1986. A controlled internal drug-release dispenser containing progesterone for control of the estrous cycle of ewes. Theriogenology 26(6):847-856.

Arendt, J., A. M. Symons, J. English, A. L. Poulton, and I. Tobler. 1988. How does melatonin control seasonal reproductive cycles? Reprod. Nutr. Develop. 28:387-397.

Baird, D. T., and R. J. Scaramuzzi. 1976. Changes in the secretion of ovarian steroids and pituitary luteinizing hormone in the peri-ovulatory period in the ewe: The effect of progesterone. J. Endocrinol. 70:237-245.

Bartlewski, P. M., A. P. Beard, and N. C. Rawlsings. 1999. An ultrasonographic study of luteal function in breeds of sheep with different ovulation rates. Theriogenology 52:115-130.

Bartlewski, P. M., T. E. Baby, and J. L. Giffin. 2011. Reproductive cycles in sheep. Anim. Reprod. Sci. 124:259-268.

Bazer, F. W., T. L. Ott, and T. E. Spencer. 1998. Maternal recognition of pregnancy: comparative aspets. Tropho. Res. 12:375-386.

Caldwell, B. V., S. A. Tillson, W. A. Brock, and L. Speroff. 1972. The effects of exogenous progesterone and estradiol on Prostaglandin F levels in ovariectomized ewes. Prostaglandins 1:217-228.

Carlson, K. M., H. A. Pohl, J. M. Marcek, R. K. Muser, and J. E. Wheaton. 1989. Evaluation of progesterone controlled internal drug release dispensers for synchronization of estrus in sheep. Anim. Reprod. Sci. 18:205-218.

Convey, E. M. 1973. Neuroendocrine relationships in farm animals: a review. J. Ani. Sci. 37(3):745-757.

Cushwa, W. T., G. E. Bradford, G. H. Stabenfeldt, Y. M. Berger, and M. R. Dally. Ram influence on ovarian and sexual activity in anestrous ewes: effects of isolation of ewes from rams before joining and date of ram introduction. J. Anim. Sci. 70:1195-1200.

Daniel, J. A., S. W. Sterle, E. L. McFadin-Buff, and D. H. Keisler. 2001. Breeding ewes out-ofseason using Melengestrol acetate, one injection of progesterone, or a controlled internal drug releasing device. Theriogenology 56:105-110. 
Dixon, A. B., M. Knights, J. L. Pate, P. E. Lewis, and E. K. Inskeep. 2006. Reproductive performance of ewes after 5-day treatment with intravaginal inserts containing progesterone in combination with injection of prostaglandin $F_{2 \alpha}$. Reprod. Domest. Anim. 41:142-148.

Downey, B. R. 1980. Regulation of the estrous cycle in domestic animals - a review. Can. Vet. J. 21:301-306.

FDA. 2009. Freedom of information summary: Original new animal drug application. Accessed March 27, 2012. http://www.fda.gov/downloads/AnimalVeterinary/Products/ ApprovedAnimalDrugProducts/FOIADrugSummaries/UCM190797.pdf.

Glimp, H. A. Effect of breed and mating season on reproductive performance of sheep. 1971. J. Anim. Sci. 32:1176-1182.

Godfrey, R. W., J. R. Collins, E. L. Hensley, and J. E. Wheaton. 1999. Estrus synchronization and artificial insemination of hair sheep ewes in the tropics. Theriogenology 51:985997.

Gordon, I. 1997. Controlled Reproduction in Sheep and Goats. Vol. 2. Cambridge, UK: CAB International.

Gordon, I. 2004. Reproductive Techonologies in Farm Animals. Trowbridge, UK: CABI Publishing.

Hackett, A. J., and H. A. Robertson. 1980. Effect of dose and time injection of prostaglandin PGF2 $\alpha$ in cycling ewes. Theriogenology 13:347-351.

Hafez, E. S. E. and B. Hafez. 2000. Reproduction in Farm Animals. $7^{\text {th }}$ Ed. Philadelphia, PA: Lippincott Williams and Wilkins.

Hamra, A. H., Y. G. Massri, J. M. Marcek, and J. E. Wheaton. 1986. Plasma progesterone levels in ewes treated with progesterone-controlled internal drug-release dispensers, implants and sponges. Anim. Reprod. Sci. 11:187-194.

Hamra, A. H., J. W. McNally, J. M. Marcek, K. M. Carlson, and J. E. Wheaton. 1989. Comparison of progesterone sponges, cronolone sponges and controlled internal drug release dispensers on fertility in anestrous ewes. Anim. Reprod. Sci. 18:219-226.

Hansel, W., P. W. Concannon, and J. H. Lukaszewska. 1973. Corpora lutea of the large domestic animals. Biol. Reprod. 8:222-245.

Hansel, W., and E. M. Convey. 1983. Physiology of the estrous cycle. J. Anim. Sci. 57:404424. 
Hashemi, M., M. Safdarian, and M. Kafi. 2006. Estrous response to synchronization of estrus using different progesterone treatments outside the natural breeding season in ewes. Small Rumin. Res. 65:279-283.

Howland, B. E., A. M. Akbar, and F. Stormshak. 1971. Serum LH levels and luteal weight in ewes following a single injection of estradiol. Biol. Reprod. 5:25-29.

Hulet, C. V., M. Shelton, J. R. Gallagher, and D. A. Price. 1974. Effects of origin and environment on reproductive phenomena in Rambouillet ewes. I. Breeding season and ovulation. J. Anim. Sci. 38(6):1210-1223.

Husein, M. Q., and R. T. Kridli. 2002. Reproductive responses of Awassi ewes treated with either naturally occurring progesterone or synthetic progestagen. Asian-Aust. J. Anim. Sci. 15(9):1257-1262.

Jabbar, G., S. H. Umberger, and G. S. Lewis. 1994. Melengestrol acetate and norgestomet for the induction of synchronized estrus in seasonally anovular ewes. J. Anim. Sci. 72:30493054 .

Karsch, F. J., B. Malpaux, N. L. Wayne, and J. E. Robinson. 1988. Characteristics of the melatonin signal that provide the photoperiodic code for timing seasonal reproduction in the ewe. Reprod. Nutr. Develop. 28:459-472.

Knight, T. W., and P. R. Lynch. 1980. Source of ram pheromones that stimulate ovulation in the ewe. Anim. Reprod. Sci. 3:133-136.

Knights, M., T. Hoehn, P. E. Lewis, and E. K. Inskeep. 2001a. Effectiveness of intravaginal progesterone inserts and FSH for inducing synchronized estrus and increasing lambing rate in anestrous ewes. J. Anim. Sci. 79:1120-1131.

Knights, M., T. D. Maze, P. J. Bridges, P. E. Lewis, and E. K. Inskeep. 2001b. Short-term treatment with a controlled internal drug releasing (CIDR) device and FSH to induce fertile estrus and increase prolificacy in anestrous ewes. Theriogenology 55:1181-1191.

Knights, M., Q. S. Baptiste, A. B. Dixon, J. L. Pate, D. J. Marsh, E. K. Inskeep, and P. E. Lewis. 2003. Effects of dosage of FSH, vehicle and time of treatment on ovulation rate and prolificacy in ewes during the anestrous season. Sm. Rumin. Resea. 50:1-9.

Leonhardt, S. A., and D. P. Edwards. 2002. Mechanisms of action of progesterone antagonists. Exp. Biol. Med. 227:969-980.

Lincoln, G. A. 1992. Photoperiod-pineal-hypothalamic relay in sheep. Anim. Reprod. Sci. 28: 203-217. 
Martin, G. B., C. M. Oldham, Y. Cognie, and D. T. Pearce. 1986. The physiological responses of anovulatory ewes to the introduction of rams - a review. Livest. Prod. Sci. 15:219247.

McCracken, J. A., D. T. Baird, and J. R. Goding. 1971. Factors affecting the secretion of steroids from the transplanted ovary in the sheep. Rec. Prog. Horm Res. 27:537-582.

McDonald, L. E. 1980. Veterinary Endocrinology and Reproduction. $3^{\text {rd }}$ Ed. Philadelphia, PA: Lea \& Febiger.

Morrical, D. G., C. R. Youngs, and A. McClain. 1997. The influence of MGA and PG 600 on the out of season reproductive performance of ewes. Iowa State University Extension Sheep Research Report. A.S. Leaflet R1475.

Murdoch, W. J. 1985. Follicular determinants of ovulation in the ewe. Domes. Anim. Endocrin. 2:105-113.

National Research Council. 2008. Change in the sheep industry in the United States: Making the transition from tradition. Washington, D.C.: The National Academies Press.

Notter, D. R. 2002. Opportunities to reduce seasonality of breeding in sheep by selection. Sheep and Goat Research J. 17(3):21-32.

Pant, H. C., C. R. N. Hopkinson, and R. J. Fitzpatrick. 1977. Concentrations of oestradiol, progesterone, luteinizing hormone and follicle-stimulating hormone in the jugular venous plasma of ewes during the oestrous cycle. J. Endocrinol. 73:247-255.

Patterson, D. J., G. H. Kiracofe, J. S. Stevenson, and L. R. Corah. Control of the bovine estrous cycle with Melengestrol acetate (MGA): a review. J. Anim. Sci. 67:1895-1906.

Perkins, A., and J. A. Fitzgerald. 1994. The behavioral component of the ram effect: the influence of ram sexual behavior on the induction of estrus in anovulatory ewes. $\mathrm{J}$. Anim. Sci. 72:51-55.

Powell, M. R., M. Kaps, W. R. Lamberson, and D. H. Keisler. 1996. Use of Melengestrol acetebased treatments to induce and synchronize estrus in seasonally anestrous ewes. J. Anim. Sci. 74:2292-2302.

Randel, R. D., M. A. Lammoglia, A. W. Lewis, D. A. Neuendorff, and M. J. Guthrie. 1996. Exogenous PGF2 $\alpha$ enhanced GnRH-induced LH release in postpartum cows. Theriogenology 45(3):643-654.

Rhodes, L., and P. W. Nathanielsz. 1988. Comparison of a controlled internal drug release device containing progesterone with intravaginal medroxyprogesterone sponges for estrus synchronization in ewes. Theriogenology 30(4):831-836. 
Robinson, J. E., and F. J. Karsch. 1988. Timing the breeding season of the ewe: what is the role of daylength? Reprod. Nutr. Develop. 28:365-374.

Romano, J. E. 2004. Synchronization of estrus using CIDR, FGA or MAP intravaginal pessaries during the breeding season in Nubian goats. Small Rumin. Res. 55:15-19.

Rosa, H. J. D., and M. J. Bryant. 2003. Seasonality of reproduction in sheep. Small Rumin. Res. 48:155-171.

Safranski, T. J., W. R. Lamberson, and D. H. Keisler. 1992. Use of Melengestrol acetate and gonadotropins to induce fertile estrus in seasonally anestrous ewes. J. Anim. Sci. 70:2935-2942.

Schinckel, P. G. 1954. The effect of the presence of the ram on the ovarian activity of the ewe. Aust. J. Agr. Res. 5(3):465-469.

Schneider, F. A. and D. M. Hallford. 1996. Use of a rapid progesterone radioimmunoassay to predict pregnancy and fetal numbers in ewes. Sheep and Goat Research J. 12(1):33-38.

Senger, P. L., 2005. Pathways to Pregnancy and Parturition. $2^{\text {nd }}$ Ed. Pullman, WA: Current Concepts.

Titi, H. H., R. T. Kridli, and M. A. Alnimer. 2010. Estrus synchronization in sheep and goats using combinations of GnRH, progestagen and prostaglandin $\mathrm{F}_{2 \alpha}$. Reprod. Domest. Anim. 45:594-599.

Underwood, E. J., F. L. Shier, and N. Davenport. 1944. Studies in sheep husbandry in W.A. V. The breeding season of Merino, Crossbred and British breed ewes in the agricultural districts. J. Ag. West. Aust. 2:135-143.

Van Cleeff, J., F. J. Karsch, and V. Padmanabhan. 1998. Characterization of endocrine events during the periestrous period in sheep after estrous synchronization with controlled internal drug release (CIDR) device. Theriogenology 15(1):23-34.

Watson, R. H., and H. M. Radford. 1960. The influence of rams on onset of oestrus in Merino ewes in the spring. Aust. J. Agr. Res. 11(1):65-71.

Wayne, N. L., B. Malpaux, and F. J. Karsch. 1989. Social cues can play a role in timing onset of the breeding season of the ewe. J. Reprod. Fert. 87:707-713.

Weems, C. W., Y. S. Weems, and R. D. Randel. 2006. Prostaglandins and reproduction in female farm animals. The Vet. J. 171:206-228.

Wheaton, J. E., H. F. Windels, and L. J. Johnston. 1992. Accelerated lambing using exogenous progesterone and the ram effect. J. Anim. Sci. 70:2628-2635. 
Wheaton, J. E., K. M. Carlson, H. F. Windels, and L. J. Johnston. 1993. CIDR: A new progesterone-releasing intravaginal device for induction of estrus and cycle control in sheep and goats. Anim. Reprod. Sci. 33:127-141.

Wildeus, S. 2000. Current concepts in synchronization of estrus: sheep and goats. J. Anim. Sci. $77: 1-14$.

Windorski, E. J., C. S. Schauer, A. K. Wurst, E. K. Inskeep, and J. S. Luther. 2008. Effects of Melengestrol acetate and P.G. 600 on fertility in Rambouillet ewes outside the natural breeding season. Theriogenology 70:227-232. 